\title{
The Danger Signal Extracellular ATP Is Involved in the Immunomediated Damage of $\alpha$-Sarcoglycan-Deficient Muscular Dystrophy
}

Elisabetta Gazzerro, ${ }^{\star \dagger}$ Serena Baratto, ${ }^{\ddagger}$ Stefania Assereto, ${ }^{*}$ Simona Baldassari, ${ }^{*}$ Chiara Panicucci, ${ }^{\ddagger}$ Lizzia Raffaghello, Paolo Scudieri, " Davide De Battista, "Chiara Fiorillo, ${ }^{*}$ Stefano Volpi, ${ }^{* *}$ Linda Chaabane, "Mauro Malnati, Graziella Messina, Santina Bruzzone, ${ }^{\ddagger}$ Elisabetta Traggiai, ${ }^{\S \S}$ Fabio Grassi, ${ }^{\Phi థ ा \|} \| * * *$ Carlo Minetti, ${ }^{*}$ and Claudio Bruno

\begin{abstract}
From the Pediatric Neurology and Muscle Disease Unit,* the Center of Translational and Experimental Myology, ${ }^{\ddagger}$ the Stem Cell Laboratory and Cell Therapy Center ${ }^{\S}$ and the Pediatria II Unit, ${ }^{* *}$ IRCCS Istituto Giannina Gaslini, Genova, Italy; the Charite Universität-Experimental and Clinical Research Center, ${ }^{\dagger}$ Berlin, Germany; the Telethon Institute of Genetics and Medicine, "Napoli, Italy; the Unit of Human Virology, Division of Immunology, Transplantation and Infectious Disease, Ospedale San Raffaele, Milano, Italy; the Departments of Biosciences ${ }^{\dagger \dagger}$ and Medical Biotechnologies and Translational Medicine, ${ }^{\mathbf{T}}$ University of Milan, Milan, Italy; the Department of Experimental Medicine, ${ }^{\ddagger \ddagger}$ University of Genova, Genova, Italy; the Novartis Institute for Research in Biomedicine, ${ }^{\S \subseteq}$ Basel, Switzerland; the Institute for Research in Biomedicine, "III Università della Svizzera Italiana, Bellinzona, Switzerland; and the Istituto Nazionale Genetica Molecolare "Romeo ed Enrica Invernizzi”,*** Milan, Italy
\end{abstract}

Accepted for publication October 16, 2018.

Address correspondence to Claudio Bruno, M.D., Ph.D., Center of Translational and Experimental Myology, Istituto Giannina Gaslini, Via G Gaslini, 5, Genova 16147, Italy; or Elisabetta Gazzerro, M.D., Charité Universität-

Experimental and Clinical Research Center, Lindenberger Weg 80, Berlin 13125,

Germany. E-mail:

claudiobruno@gaslini.org or elisabetta.gazzerro@charite.de.
In muscular dystrophies, muscle membrane fragility results in a tissue-specific increase of dangerassociated molecular pattern molecules (DAMPs) and infiltration of inflammatory cells. The DAMP extracellular ATP (eATP) released by dying myofibers steadily activates muscle and immune purinergic receptors exerting dual negative effects: a direct damage linked to altered intracellular calcium homeostasis in muscle cells and an indirect toxicity through the triggering of the immune response and inhibition of regulatory $T$ cells. Accordingly, pharmacologic and genetic inhibition of eATP signaling improves the phenotype in models of chronic inflammatory diseases. In $\alpha$-sarcoglycanopathy, eATP effects may be further amplified because $\alpha$-sarcoglycan extracellular domain binds eATP and displays an ecto-ATPase activity, thus controlling eATP concentration at the cell surface and attenuating the magnitude and/or the duration of eATP-induced signals. Herein, we show that in vivo blockade of the eATP/P2X purinergic pathway by a broad-spectrum P2X receptor-antagonist delayed the progression of the dystrophic phenotype in $\alpha$-sarcoglycan-null mice. eATP blockade dampened the muscular inflammatory response and enhanced the recruitment of forkhead box protein P3-positive immunosuppressive regulatory $\mathrm{CD}^{+}{ }^{+} \mathrm{T}$ cells. The improvement of the inflammatory features was associated with increased strength, reduced necrosis, and limited expression of profibrotic factors, suggesting that pharmacologic purinergic antagonism, altering the innate and adaptive immune component in muscle infiltrates, might provide a therapeutic approach to slow disease progression in $\alpha$ sarcoglycanopathy. (Am J Pathol 2019, 189: 354-369; https://doi.org/10.1016/j.ajpath.2018.10.008)
Sarcoglycanopathies represent a subgroup of autosomal recessive limb-girdle muscular dystrophies (LGMDs) caused by mutations in one of the four sarcoglycan (SG) genes, which encode four transmembrane proteins $(\alpha-, \beta-, \gamma-$, or $\delta$ SG) organized in a tetrameric structure on the cell surface. ${ }^{1}$

The clinical phenotype of $\alpha$-sarcoglycanopathy (LGMD2D; Online Mendelian Inheritance in Man number 608099) is heterogeneous. ${ }^{2}$ Progressive degeneration of skeletal muscle leads to loss of ambulation, respiratory insufficiency, and often premature death in the early thirties. ${ }^{3}$ The rapidity of disease progression and the age of onset are variable, ranging from severe forms with onset in

Supported by Telethon-Italy grant GEP12053 (C.B.) and Cinque per mille dell'IRPEF-Finanziamento della ricerca sanitaria, Finanziamento Ricerca Corrente, Ministero Salute (L.R.).

E.G., S.Bar., and S.A. contributed equally to this work.

Disclosures: None declared. 
the first decade of life and rapid evolution, to milder forms with later onset and slower progression. Currently, no treatment is available for these patients.

Sarcoglycans and dystrophin are main components of the dystrophin-glycoprotein complex, the crucial structural linkage between the intracellular cytoskeleton and the extracellular matrix that provides stability to the sarcolemma and offers muscle fibers protection from muscle contraction-induced stress. In both sarcoglycanopathies and dystrophinopathies, dystrophin-glycoprotein complex disruption leads to a mechanically weaker muscle plasma membrane that is easily damaged during contraction, allowing release of intracellular molecules, which act as damageassociated molecular pattern molecules (DAMPs). ${ }^{4}$ These self-molecules execute precise intracellular tasks in both innate and adaptive immunity, exerting disparate functions when released into the extracellular space. Among DAMPs, extracellular ATP (eATP) and its derivates are pleiotropic regulators of cell function. ${ }^{5}$ In muscle, the primary function of ATP is energy transfer; however, after cell damage, it is quickly released in the extracellular space, where it acts as DAMP. Once in the extracellular space, eATP activates plasma-membrane nonselective ion channels purinergic $\mathrm{P} 2 \mathrm{X}$ 1 to 7 receptors and P2Y 1, 2, 4, 6, and 11 to 14 , guanine nucleotide binding protein-coupled receptors. ${ }^{6,7}$ The role of eATP and P2X purinergic signal on $m d x$ dystropathology has been recently well established. We have shown that blockade of eATP/P2X purinergic signaling by periodate-oxidase ATP (oATP) delayed the progression of the dystrophic phenotype, dampening the local inflammatory response in dystrophindeficient $m d x$ mice. $^{8}$ These results are in agreement with the phenotype displayed by $m d x / \mathrm{P} 2 \mathrm{X} 7$ double-knockout mice, which showed a reduction of the inflammatory and fibrotic response in skeletal muscles and heart. ${ }^{9}$

We hypothesized that the role of eATP may be equally relevant in $\alpha$-SG deficiency because this protein displays in its extracellular domain an ecto-ATPase activity, which allows conversion of ATP to the inactive form ADP. ${ }^{10,11}$

Herein, we provide the first set of evidences of a pathogenetic role of eATP in $\alpha$-sarcoglycanopathy. Short-term pharmacologic inhibition of eATP signaling improved muscular function and morphology, inhibited the effector adaptive and the innate immune response, reduced the expression of profibrotic factors, and enhanced forkhead box protein P3-positive $\left(\mathrm{Foxp}^{+}\right) \mathrm{CD}^{+}{ }^{+}$T-regulatory cell muscle infiltration in $\alpha$-sarcoglycan ( $\mathrm{Sgca}$ ) mice. It is thus feasible that $\alpha$-SG deficiency can amplify the magnitude of eATP-induced signals, worsening the immunomediated damage in LGMD2D patients.

\section{Materials and Methods}

\section{In Vivo Treatment with oATP}

Sgca knockout mice [kindly donated by Prof. Giulio Cossu (University of Manchester, Manchester UK)] were treated with oATP at $6 \mathrm{mmol} / \mathrm{L}$ or phosphate-buffered saline (PBS) alone daily for 4 weeks by i.p. injection and were sacrificed at the end of treatment by carbon dioxide inhalation. A group of age-matched wild-type (WT) C57Bl/6J male mice was used as internal control. The experiment was repeated in two separate 4-week trials, which both included 5 to 7 mice in each experimental group. Thus, the results are indicative of at least 10 animals per group. The Sgca mice were randomly assigned to the experimental groups, and the testing of samples was performed blindly (S.A. and S.Bal.).

Blood samples were collected by intracardial puncture at the end of the fourth week of treatment and centrifuged for 10 minutes at $7000 \times \mathrm{g}$. Immediately after centrifugation, the serum was isolated and stored at $-20^{\circ} \mathrm{C}$. Serum creatine kinase levels were measured using the creatine kinase$\mathrm{N}$-acetyl cysteine quantitative system, according to manufacturer's instructions (BPC BioSED, Rome, Italy).

All animal experiments were performed in accordance with the Swiss Federal Veterinary Office guidelines and authorized by the Animal Studies Committee of Cantonal Veterinary.

\section{Four-Limb Hanging Test}

At the beginning of the study and at the end of the second and fourth week of treatment, the muscle strength of oATPtreated, PBS-treated Sgca, and WT control mice was scored through the four-limb hanging test. In this method, mice are subjected to a 180 -second lasting hanging test, during which a falling score is recorded. In each of the two treatments, all of the mice had to hang for three trials, and the average maximum hanging time of the three trials was measured (standard operating procedure, http://www.treat-nmd.eu/research/ preclinical/preclinical-efficacy-standards, last accessed December 1, 2017).

\section{Reagents and Antibodies}

oATP (Sigma-Aldrich, St. Louis, MO) was reconstituted at a final concentration of $100 \mathrm{mmol} / \mathrm{L}$ in PBS and stored at $-80^{\circ} \mathrm{C}$; the reconstituted drug was thawed and diluted in PBS at $6 \mathrm{mmol} / \mathrm{L}$ immediately before use. Lipopolysaccharide (LPS; Sigma-Aldrich) was reconstituted at a final concentration of $1 \mathrm{mg} / \mathrm{mL}$ in Hanks' balanced salt solution and stored at $-20^{\circ} \mathrm{C}$, ATP (Sigma-Aldrich) was reconstituted at $100 \mathrm{mmol} / \mathrm{L}(\mathrm{pH} 7)$ in water with sodium hydroxide and stored at $-20^{\circ} \mathrm{C}$, and benzoyl ATP (BzATP; Sigma-Aldrich) was reconstituted at $10 \mathrm{mmol} / \mathrm{L}$ in water and stored at $-20^{\circ} \mathrm{C}$.

The antibodies and dilutions used in the study include the following: mouse monoclonal antibody to collagen type I [1:500 for Western blot (WB) analysis] and rat monoclonal antibody to Ly6C [1:500 for immunohistochemistry (IHC)] from Abcam (Cambridge, UK); rat monoclonal antibody to CD45 (1:10 for IHC) from BD Pharmigen (San Jose, CA); mouse monoclonal antibody to activating signal 
cointegrator-1 (ASC-1) (1:500 for WB analysis) and rabbit polyclonal antibodies to glyceraldehyde phosphate dehydrogenase (1:500 for WB analysis) from Santa Cruz Biotechnology (Dallas, TX); rabbit polyclonal antibody to CD3 (1:20 for IHC); rabbit polyclonal antibodies to P2X7 receptor ( $\mathrm{R}$; extracellular) and $\mathrm{P} 2 \mathrm{X} 4 \mathrm{R}$ (1:50 and 1:300, respectively, for immunofluorescence) from Alomone Labs (Jerusalem, Israel); rabbit polyclonal antibody to transforming growth factor (TGF)- $\beta$ (1:1000 for WB analysis) from Cell Signaling Technology (Danvers, MA); mouse monoclonal antibody to CD39 (1:1000) from Abcam; mouse monoclonal antibody to $\alpha$-SG (1:100 for WB analysis) from Novocastra (Newcastle upon Tyne, UK); mouse monoclonal antibody to $\beta$-dystroglycan (1:50 for WB analysis) from Novocastra; mouse monoclonal anticaveolin-3 (1:10,000 for WB analysis) from BD Bioscience (Milan, Italy); mouse monoclonal antibody to myosin heavy chain (fast; 1:1000 for WB analysis) from Novocastra; rabbit anti-mouse IgG horseradish peroxidase-conjugated (1:700 for WB analysis) antibodies from Dako (Glostrup, Denmark); donkey anti-rabbit IgG horseradish peroxidase-conjugated (1:5000 for WB analysis) antibodies from GE Health Care (Little Chalfont, UK); mouse monoclonal anti-rat $\kappa$ and $\lambda$ light chain horseradish peroxidase-conjugated (1:100 for IHC) antibody from Sigma-Aldrich; rat monoclonal to FOXP3 (1:20 for IHC) from eBioscience (Waltham, MA); and goat anti-mouse AlexaFluor 488 and donkey anti-rat AlexaFluor 594 (1:750 for immunofluorescence) antibodies from Thermo Fisher Scientific (Waltham, MA). The EnVision Detection System Peroxidase/Diaminobenzidine, rabbit and mouse, was from Dako. The Annexin A5-FITC/7-AAD Kit was purchased from Beckman Coulter (Marseille, France).

\section{Satellite Cell Isolation from Total Muscle}

Satellite cells were isolated from WT and Sgca mice at passage 8 to passage 10 . Forelimb, hind limb, and diaphragm muscles were dissected, mechanically cut, and enzymatically digested at $37^{\circ} \mathrm{C}$ under constant shaking with a solution containing collagenase I $(100 \mu \mathrm{g} / \mathrm{mL}$; SigmaAldrich), dispase (500 $\mu \mathrm{g} / \mathrm{mL}$; Gibco, Waltham, MA), and DNaseI (100 $\mu \mathrm{g} / \mathrm{mL}$; Roche, Basel, Switzerland) in PBS (Sigma-Aldrich). Undigested tissue was precipitated for 5 minutes, and the supernatant was centrifuged for 5 minutes at $1200 \times g$. The cell pellet was resuspended in Dulbecco's modified Eagle's medium plus 10\% fetal bovine serum, $1 \%$ L-glutamine, $1 \%$ penicillin/streptomycin, and $1 \%$ gentamicin; then, it was preplated in 150-mm Petri uncoated dishes for 1 hour. After preplating, the nonadherent satellite cell-enriched population was collected and plated in collagen-coated (collagen from calf skin; Sigma-Aldrich) 90-mm Petri dishes at a density of 30,000 cells per Petri dish. After a few days in proliferation, the myoblasts were eventually plated at high density in differentiation medium (Dulbecco's modified Eagle's medium, 10\% donor horse serum, $1 \%$ L-glutamine, $1 \%$ penicillin/streptomycin, $1 \%$ gentamicin, and $2.5 \mathrm{ng} / \mathrm{mL}$ basic fibroblast growth factor).

\section{Histologic Studies}

Sections ( $7 \mu \mathrm{m}$ thick) from gastrocnemii (GN) and anterior tibialis muscles isolated from PBS-treated mice, oATP-Sgca mice, and WT controls were cut on a cryostat and stained with standard hematoxylin and eosin and acid phosphatase for inflammatory reactions and Masson trichrome stain.

Image analysis in terms of area fraction quantification, signal intensity, and object counting was performed using semiautomated measurement tools in NIS-Elements AR software version 4.20.00 (Laboratory Imaging, s.r.o., Prague, Czech Republic). Central nucleation (expressed as percentage of the total nuclei in each section) was quantified in a blinded manner (S.A. and S.Bal.) in three sections for each muscle $(n=10$ mice for each experimental group, $n=400$ to 600 myofibers per single animal) with the Axioplan Imager M2 microscope software AxioVs40 version 4.8.2.0 (Zeiss, Oberkochen, Germany). Paraffin-embedded diaphragms isolated from PBStreated oATP-Sgca and WT control mice were cut in cross section at the midbelly of the muscle ( $7 \mu \mathrm{m}$ thick). After deparaffinization, the slides were stained with hematoxylin and $\operatorname{eosin}^{12}$ and Picrosirius red staining for collagen fibers.

\section{Immunohistochemistry}

Cryosections ( $5 \mu \mathrm{m}$ thick) of $\mathrm{GN}$ and anterior tibialis muscles isolated from PBS-treated, oATP-Sgca, and WT control mice were fixed in acetone at $-20^{\circ} \mathrm{C}$ for 10 minutes, washed three times in PBS, and then washed twice in $0.025 \%$ PBS/Triton. Sections were incubated in $8 \%$ bovine serum albumin in PBS (blocking solution) for 1 hour at room temperature. Then, sections were incubated with primary antibodies diluted in $1 \%$ bovine serum albumin in PBS solution overnight at $4^{\circ} \mathrm{C}$. The next day, sections were washed two times with $0.025 \%$ Triton in PBS, incubated 15 minutes in $0.3 \% \mathrm{H}_{2} \mathrm{O}_{2}$ in PBS, and subsequently incubated with an Envision secondary antibody for 1 hour. After being rinsed two times with PBS (5 minutes each), the sections were stained with a diaminobenzidine substrate solution (freshly made just before use), counterstained with hematoxylin, washed with deionized water, dehydrated through five changes of alcohol $(70 \%, 90 \%, 95 \%, 100 \%$, and $100 \%)$ for 1 minute each, cleared in two changes of xylene (3 minutes each), and mounted with a Vectashield mounting medium (Vector Laboratories, Burlingame, CA). Slides were observed under a Leica Diaplan microscope (Leica, Wetzlar, Germany). The number of positive cells was blindly counted (S.Bar. and S.A.) on the whole sections per mouse. The total area of the section was measured and expressed in arbitrary units.

For immunofluorescence, unfixed cryosections $(5 \mu \mathrm{m}$ thick) of GN and anterior tibialis muscles were incubated in common antibody diluent (BioGenex, San Ramon, CA) for 
Table 1 List of Primers Used in This Study

\begin{tabular}{|c|c|c|}
\hline Name & Accession number & Primer sequence \\
\hline mPTPRC-F & NM_001111316.2 & 5'-ATCTATCCCGCCCAGAATGG-3' \\
\hline mPTPRC-R & NM_001111316.2 & 5'-TGCTGTCTTCCTGGGCTTTA-3' \\
\hline mADGRE-1-R & NM_010130.4 & 5'-GTGCCCAGAGTGGATGTCT-3' \\
\hline mEGR2-F & NM_010118 & 5'-GGACCCAGGTCTCATTCCTA-3' \\
\hline mEGR2-R & NM_010118 & $5^{\prime}$-GAGTCCAGAGGACAGGGAAA- $3^{\prime}$ \\
\hline $\mathrm{mCD} 4-\mathrm{F}$ & NM_013488.2 & 5'-GACAGTGTTCCTGGCTTGCG-3' \\
\hline $\mathrm{mCD} 4-\mathrm{R}$ & NM_013488.2 & $5^{\prime}-$ GCACCTGACACAGCAGAGGA- $3^{\prime}$ \\
\hline $\mathrm{mCD} 8 \mathrm{a}-\mathrm{F}$ & NM_001081110.2 & 5'-ATGGCTTCATCCCACAACAAG-3' \\
\hline$m C D 8 a-R$ & NM_001081110.2 & $5^{\prime}$-CGTGTCCCTCATGGCAGAA- $3^{\prime}$ \\
\hline mFOXP3-F & NM_001199347 & $5^{\prime}-\mathrm{CAGTCAAAGAGCCCTCACAA-3^{ \prime }}$ \\
\hline mIL10-R & NM_010548 & $5^{\prime}-\mathrm{TCACTCTTCACCTGCTCCAC-3^{ \prime }}$ \\
\hline mMYOG-F & NM_031189 & $5^{\prime}-$ AGTGAATGCAACTCCCACAG- $3^{\prime}$ \\
\hline mMYOG-R & NM_031189 & 5'-CTGTCCACGATGGACGTAAG-3' \\
\hline mSPP1-F & NM_001204201 & 5'-TGACGATGATGATGACGATG-3' \\
\hline mSPP1-R & NM_001204201 & $5^{\prime}$-GGGACGATTGGAGTGAAAGT-3' \\
\hline $\operatorname{mIFN} \gamma-\mathrm{F}$ & NM_008337 & 5'-TCCTTTGGACCCTCTGACTT-3' \\
\hline $\operatorname{mIFN} \gamma-\mathrm{R}$ & NM_008337 & $5^{\prime}-$ GTAACAGCCAGAAACAGCCA-3' \\
\hline mIL6-F & NM_001314054 & $5^{\prime}-\mathrm{CTGGAGCCCACCAAGAACGA-3^{ \prime }}$ \\
\hline mIL6-R & NM_001314054 & $5^{\prime}-$ TGTGAAGTCTCCTCTCCGGACT-3' \\
\hline mCTGF-F & NM_010217 & 5'-GAGTGTGCACTGCCAAAGAT-3' \\
\hline mCTGF-R & NM_010217 & 5'-GGCAAGTGCATTGGTATTTG-3' \\
\hline
\end{tabular}

Accession numbers from https://www.ncbi.nlm.nih.gov/pubmed/Nucleotide.

$F$, forward; R, reverse.

10 minutes and after with primary antibodies (CD45, P2X4, and $\mathrm{P} 2 \mathrm{X} 7$ antibodies) overnight at $4^{\circ} \mathrm{C}$. After three washes with PBS, sections were incubated with fluorescent secondary antibodies in common antibody diluent for 1 hour at room

Table 2 List of Primer/Probe Sets Used in This Study

\begin{tabular}{ll}
\hline Probe & Catalog number \\
\hline mP2RX1 & Mm00435460_m1 \\
mP2RX2 & Mm01202368_g1 \\
mP2RX3 & Mm00523699_m1 \\
mP2RX4 & Mm00501787_m1 \\
mP2RX5 & Mm00473677_m1 \\
mP2RX6 & Mm00440591_m1 \\
mP2RX7 & Mm00440578_m1 \\
mIL1 $\beta$ & Mm00434228_m1 \\
mGAPDH & 4352932E \\
mACTA1 & Mm00808218_g1 \\
\hline
\end{tabular}

temperature in the dark. After being washed three times with PBS, sections were mounted with Vectashield mounting medium with DAPI (Vector Laboratories). Images were obtained using a Leica SPE confocal microscope equipped with argon/He-Ne laser sources and an HCX PL APO CS $63.0 \times 1.40$ oil objective. During image acquisition, the 488 and 594 lasers were set at 20\% energy, and the emission range was between 500 and 550 and between 650 and $700 \mathrm{~nm}$ for P2X 488 and CD45 594, respectively. The photomultiplier voltage gain was set to eliminate cell autofluorescence. Single-plane images were taken at the center of cell thickness.

\section{Real-Time Quantitative PCR}

Total RNA was extracted from GN muscles (from 20 to 55 $\mathrm{mg}$ ) isolated from PBS-treated mice, oATP-Sgca mice, and WT controls, according to the manufacturer's protocol 

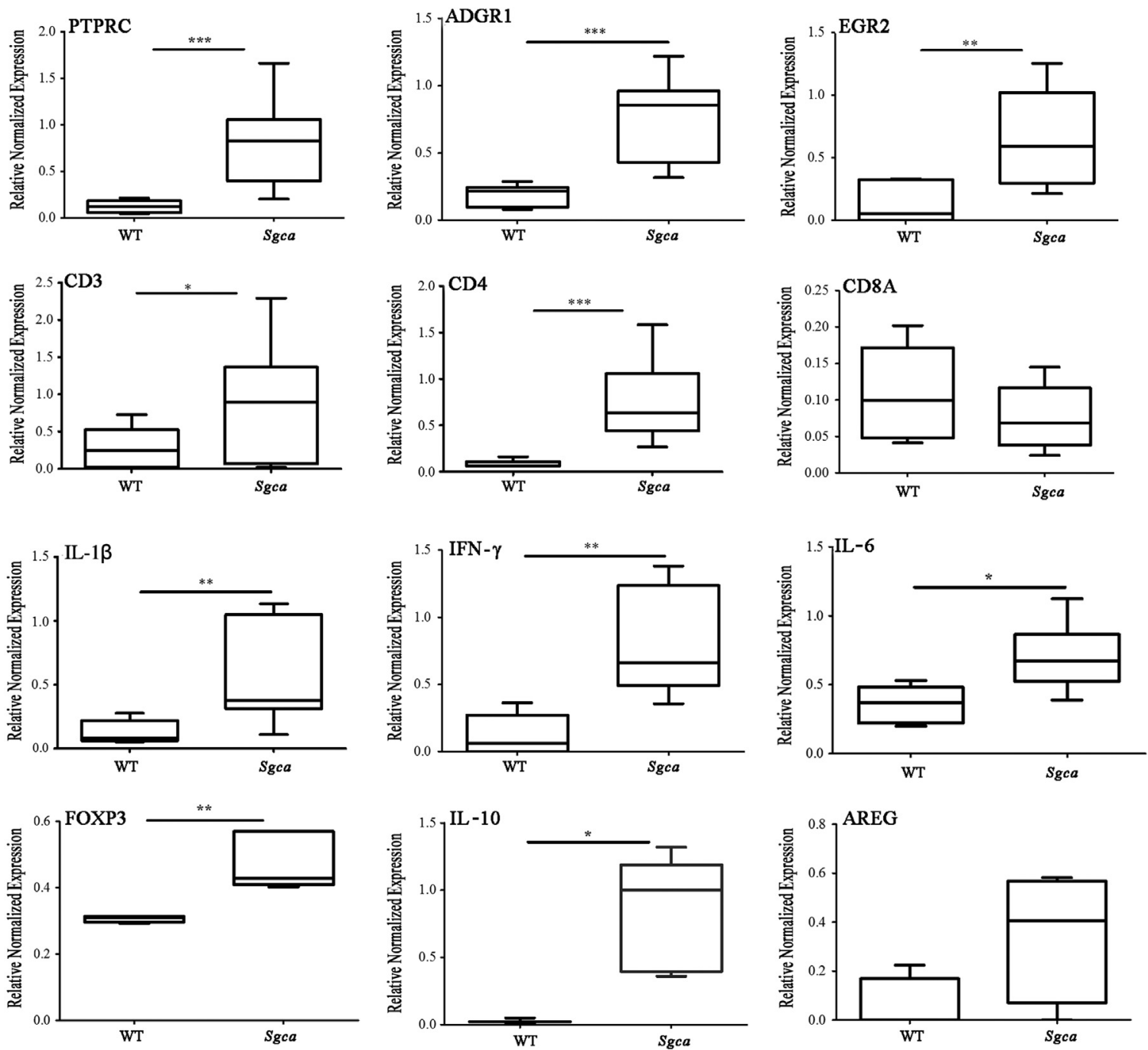

Figure 1 Inflammatory response and T-regulatory cell (Treg) activation in Sgca mice. Total RNA isolated from the gastrocnemii of $10 \mathrm{Sgca}$ and 7 age- and sex-matched WT mice was reverse transcribed. The pattern of expression of molecular markers of innate [receptor-type tyrosine-protein phosphatase C (PTPRC), adhesion G-protein-coupled receptor E1 (ADGRE1), and early growth response protein 2 (EGR2)] and adaptive [CD3, CD4, and T-cell surface glycoprotein CD8 $\alpha$ chain (CD8A)] immunity, of Treg activation [forkhead box protein P3 (FOXP3), amphiregulin (AREG), and IL-10)], and of proinflammatory cytokines [interferon (IFN) $-\gamma$, IL-1 $\beta$, and IL-6] was determined by real-time quantitative PCR. PPIA and RPL13A transcript levels were used as housekeeping genes. Data are expressed as medians \pm first and third quartiles. PTPRC: WT $=0.11$ (0.05 to 0.18), Sgca $=0.82$ (0.39 to 1.05). ADGRE1: WT $=0.21$ (0.09 to 0.24), Sgca $=0.85$ (0.43 to 0.96). EGR2: WT $=0.05$ (0.01 to 0.32), Sgca $=0.59$ (0.29 to 1.02). CD3: WT $=0.25$ (0.02 to 0.52), Sgca $=0.89$ (0.06 to 1.36). CD4: WT $=0.06$ (0.06 to 0.11), Sgca $=0.63$ (0.44 to 1.05). CD8A: WT $=0.09(0.04$ to 0.17$)$, Sgca $=0.06(0.04$ to 0.11$)$. F0XP3: WT $=0.31$ (0.30 to 0.31$)$, Sgca $=0.43$ (0.41 to 0.57). AREG: WT $=0.001$ (0.001 to 0.17$)$, Sgca $=0.40(0.07$ to 0.57$)$. IL-10: WT $=0.02(0.01$ to 0.05$)$, Sgca $=1.00(0.39$ to 1.18$)$. IL-1 1 : WT $=0.02(0.062$ to 0.21$)$, Sgca $=0.38(0.31$ to 1.05$)$. IL-6: WT $=0.37(0.22$ to 0.489$)$, Sgca $=0.67(0.52$ to 0.86$)$. IFN- $\gamma:$ WT $=0.06(0.0$ to $0.27)$, Sgca $=0.66$ (0.49 to 1.24$)$. Statistical analysis was performed using the $U$-test. ${ }^{*} P<0.05,{ }^{*} P<0.01$, and ${ }^{* * *} P<0.001$.

(DNase treatment). Quality and quantity of RNA were analyzed using a NanoDrop spectrophotometer (NanoDrop Technologes, Inc., Wilmington, DE).

The cDNA was synthesized from $350 \mathrm{ng}$ of total RNA with the iScript cDNA Synthesis Kit (Bio-Rad Laboratories, Hercules, CA). Each RNA sample was controlled for genomic DNA contamination without reverse transcriptase addition into a cDNA synthesis mixture. For receptor-type tyrosine-protein phosphatase C (CD45), adhesion G-proteincoupled receptor E1 (F4/80), early growth response protein 2 , CD3 $\varepsilon$ chain, CD4, CD8 $\alpha$ chain, interferon- $\gamma($ IFN- $\gamma$ ), IL-6, FOXP3, IL-10, amphiregulin, myogenin, osteopontin (secreted phosphorylated protein 1), connective tissue growth factor, and TGF- $\beta 1$ transcript quantification, real-time quantitative PCR (qPCR) was performed in triplicate with the $2 \times$ Sso Fast EvaGreen Supermix in the CFX96 RealTime PCR Detection System (Bio-Rad Laboratories). Specific primers for the mouse genes were designed through Beacon Designer software version 2.0 (Premier Biosoft International, Palo Alto, CA) and are listed in Table 1.

Briefly, the $15-\mu \mathrm{L}$ PCR mixture contained diluted cDNA that corresponded to $8.75 \mathrm{ng}$ of total RNA and $0.2 \mathrm{mmol} / \mathrm{L}$ of each primer. Relative expression levels were normalized using the comparative $\mathrm{Ct}(\Delta \Delta \mathrm{Ct})$ method with two 

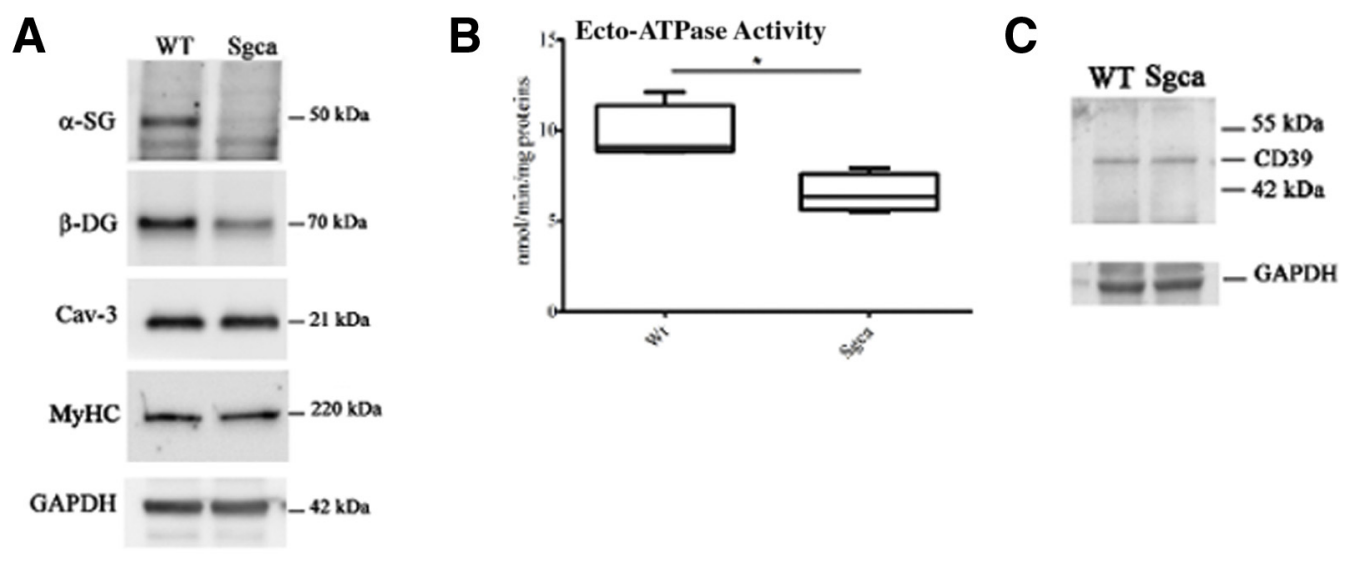

D



Figure 2 Sgca myoblasts display a decreased ecto-ATPase activity and undergo apoptosis on treatment with ATP or benzoyl ATP (BzATP). A: Total protein lysates, isolated from primary myotubes from Sgca and WT age-matched controls, were subjected to Western blot analysis. Membranes were probed with a mouse monoclonal anti- $\alpha$-SG, $\beta$-dystroglycan ( $\beta$-DG), anti-caveolin-3 (Cav-3), and myosin heavy chain (MyHC) antibody. Glyceraldehyde-3-phosphate dehydrogenase (GAPDH) was used as a loading control. Samples were run in triplicate. Representative images are shown. B: Primary myotubes isolated from Sgca and WT mice were cultured in basal medium containing ATP at $0.3 \mathrm{mmol} / \mathrm{L}$. At subsequent times $(0,5$, and 15 minutes), 100- $\mu \mathrm{L}$ aliquots of the incubations were withdrawn and ATP degradation was determined by the phosphate high-performance liquid chromatography analysis. C: Total protein lysates, isolated from primary myotubes from Sgca and WT age-matched controls, were subjected to Western blot analysis. Membranes were probed with a mouse monoclonal anti-CD39 antibody. GAPDH was used as a loading control. Samples were run in triplicate. Representative images are shown. D: Primary myotubes isolated from Sgca mice were pretreated with $1 \mu \mathrm{g} / \mathrm{mL}$ lipopolysaccharide (LPS) for 4 hours and then incubated with $3 \mathrm{mmol} / \mathrm{L}$ ATP and $300 \mu \mathrm{mol} / \mathrm{L}$ BzATP for 16 hours. The cells were stained with the Annexin A5 FITC/7-AAD Kit, and apoptosis was evaluated by flow cytometry. Data are expressed as medians \pm first and third quartiles (B); statistical analysis was performed using the $U$-test. Data are expressed as percentage of apoptotic cells $\left(\mathrm{Annexin}^{+} 7-\mathrm{AAD}^{-}+\mathrm{Annexin}^{+} 7-\mathrm{AAD}^{+}\right.$; D). One representative experiment of three performed is shown. $n=4$ wells per genotype (B). ${ }^{*} P<0.05$.

housekeeping genes (peptidylprolyl isomerase A and ribosomal protein L 13a) by the Bio-Rad CFX Maestro software 1.0 version 4.0.2325.0418. For each specific primer set, the efficiency was $>95 \%$ and a single product was seen on the melting curve analysis.

For mouse P2X receptors and IL-1 $\beta$ quantification, qPCR was performed in triplicate with the $2 \times$ Sso Fast Probes Supermix (Bio-Rad Laboratories) in a CFX96 Real-Time PCR Detection System. The 15- $\mu$ L PCR mixture contained diluted cDNA that corresponded to $12.5 \mathrm{ng}$ of total RNA, and premixed primer/probe sets were ordered from Applied Biosystems (Foster City, CA) (Table 2). Relative expression levels were normalized using the comparative $\mathrm{Ct}(\Delta \Delta \mathrm{Ct})$ method with the housekeeping gene Gapdh and actin- $\alpha 1$ (Actal, a muscle specific gene, NM_001272041.1), by the Bio-Rad CFX Maestro software.

\section{Western Blot Analysis}

Total protein lysates were isolated from PBS-treated mice, oATP-Sgca mice, and WT GN muscles, as previously described. ${ }^{8}$ Equal amounts of protein $(40$ to $120 \mu \mathrm{g})$ were resolved in $8 \%$ to $15 \%$ SDS-PAGE gel and transferred onto polyvinylidene difluoride membranes (Immobilon PVDF, Billerica, MA). Membranes were blocked with $5 \%$ bovine serum albumin in PBS/ $0.1 \%$ Tween 20. Blots were then incubated overnight at $4^{\circ} \mathrm{C}$ with primary antibodies. Horseradish peroxidase anti-IgG was used to visualize bound primary antibodies with the chemiluminescence system (Bio-Rad Laboratories). Band intensities were evaluated by densitometry using the Alliance Mini HD9 AutoAutomatic system (Uvitec, Cambridge, UK). 

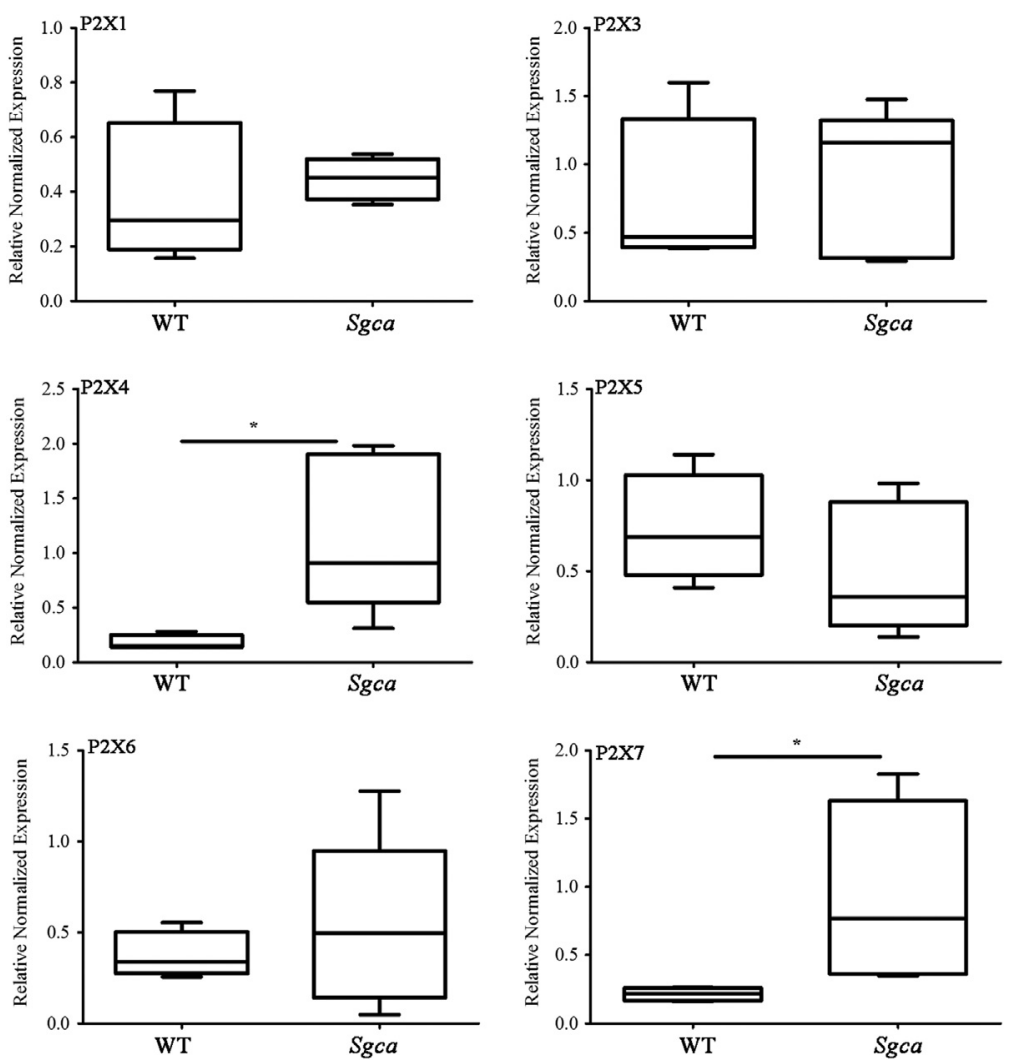

Figure $3 \quad \mathrm{P} 2 \mathrm{X} 4$ and $\mathrm{P} 2 \mathrm{X} 7$ purinergic receptors are significantly up-regulated in Sgca muscle tissue. Total RNA isolated from the gastrocnemii of 10 Sgca and 7 age- and sex-matched WT mice was reverse transcribed. The pattern of expression of P2X receptors (Rs) was determined by real-time quantitative PCR. P2X2R transcript levels were not measurable. P2X4R and P2X7R transcripts are significantly up-regulated in $\alpha$-SG-deficient mice. Gapdh and Acta1 were used as housekeeping genes. Data are expressed as medians \pm first and third quartiles. P2X4: WT $=0.147$ (0.140 to 0.249$),$ Sgca $=0.907$ (0.549 to 1.905$)$. P2X7: WT $=0.217$ (0.167 to 0.258 ), Sgca $=0.767$ (0.362 to 1.630). Statistical analysis was performed using the $U$-test. ${ }^{*} P<0.05$.

\section{Ecto-ATPase Activity}

Satellite cells were seeded in 24-well plates $\left(5.5 \times 10^{4}\right.$ cells/ well) and cultured until they completely differentiated into mature myotubes. After removal of the culture medium, cells were washed once with $1 \mathrm{~mL}$ Hanks' balanced salt solution, and $0.35 \mathrm{~mL}$ Hanks' balanced salt solution containing 0.3 $\mathrm{mmol} / \mathrm{L}$ ATP was added. At various times $(0,5$, and $15 \mathrm{mi}-$ nutes), $100-\lambda$ aliquots of the incubations were withdrawn and incubations were stopped by filtration with a multiscreen vacuum manifold using Immobilon-P membrane plates (Millipore, Bedford, MA). ATP degradation was determined by the phosphate high-performance liquid chromatography analysis, as previously described. ${ }^{13}$ Cells were lysed, and protein content in each well was determined by Bradford assay.

\section{Apoptosis}

Satellite cells were seeded in 24 -well plates $\left(6 \times 10^{4}\right.$ cells/ well) and cultured until they completely differentiated into mature myotubes. The cells were pretreated with LPS $(1 \mu \mathrm{g} / \mathrm{mL})$ for 4 hours and then incubated with $3 \mathrm{mmol} / \mathrm{L}$ ATP and $300 \mu \mathrm{mol} / \mathrm{L}$ BzATP for 16 hours. Then, myotubes were analyzed by flow cytometry, according to other studies that have adopted the same technique. ${ }^{14-16}$ Specifically, the cells were stained with the Annexin A5 FITC/7-AAD Kit, and apoptosis was evaluated by flow cytometry, according to the manufacturer's instructions. Sample analysis was performed using a Gallios cytometer (Beckman-Coulter) and Kaluza software version 1.1 (Beckman-Coulter).

\section{Statistical Analysis}

Most of the analyzed variables were not normally distributed, as confirmed by the Shapiro-Wilk test, and therefore differences of quantitative parameters between two groups of mice were analyzed by the $U$-Mann Whitney test for nonparametric data. $P<0.05$ was considered statistically significant. Data are expressed as medians \pm first and third quartiles, as described in Results and figure legends. Statistica software version 9.1 (StatSoft Co, Tulsa, OK) was used for all of the statistical analyses. Graphs were generated with Graph Pad Prism software version 6.0 (Graph Pad Software, San Diego, CA).

\section{Results}

Sgca Skeletal Muscle Displays an Increased Expression of Markers of Innate and Adaptive Immunity

To quantify the inflammatory response in muscles isolated from Sgca mice, the transcript levels of different immune cell markers and of distinct cytokines were analyzed, compared with muscles isolated from age-matched WT mice. $\alpha$-SG-deficient muscle overexpressed leukocytes as well as macrophage surface proteins. Receptor-type tyrosineprotein phosphatase C (CD45), adhesion G-protein-coupled receptor E1 (F4/80), and early growth response protein 2 
A
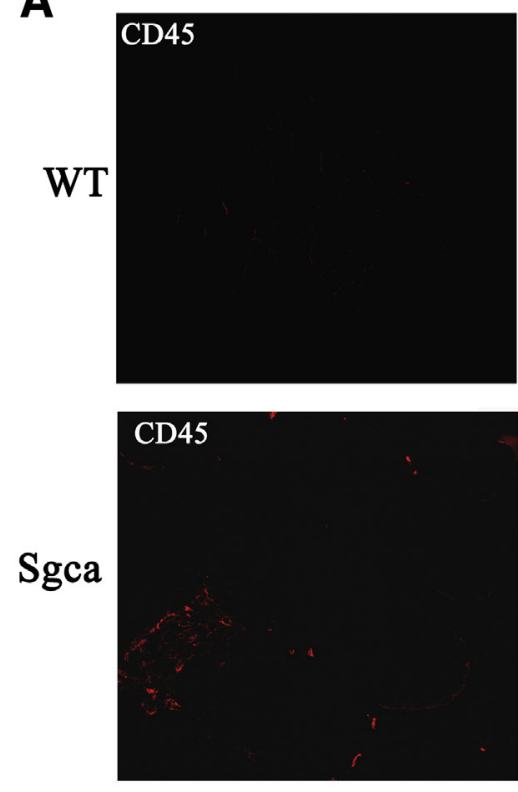

B
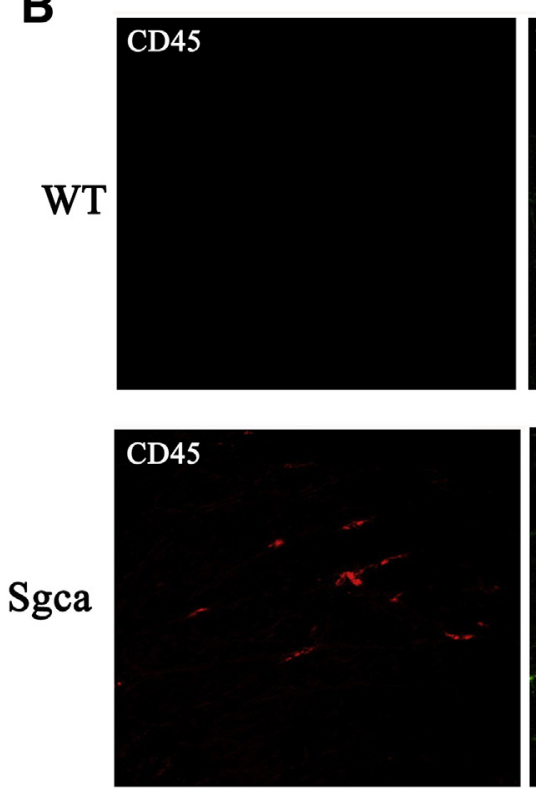
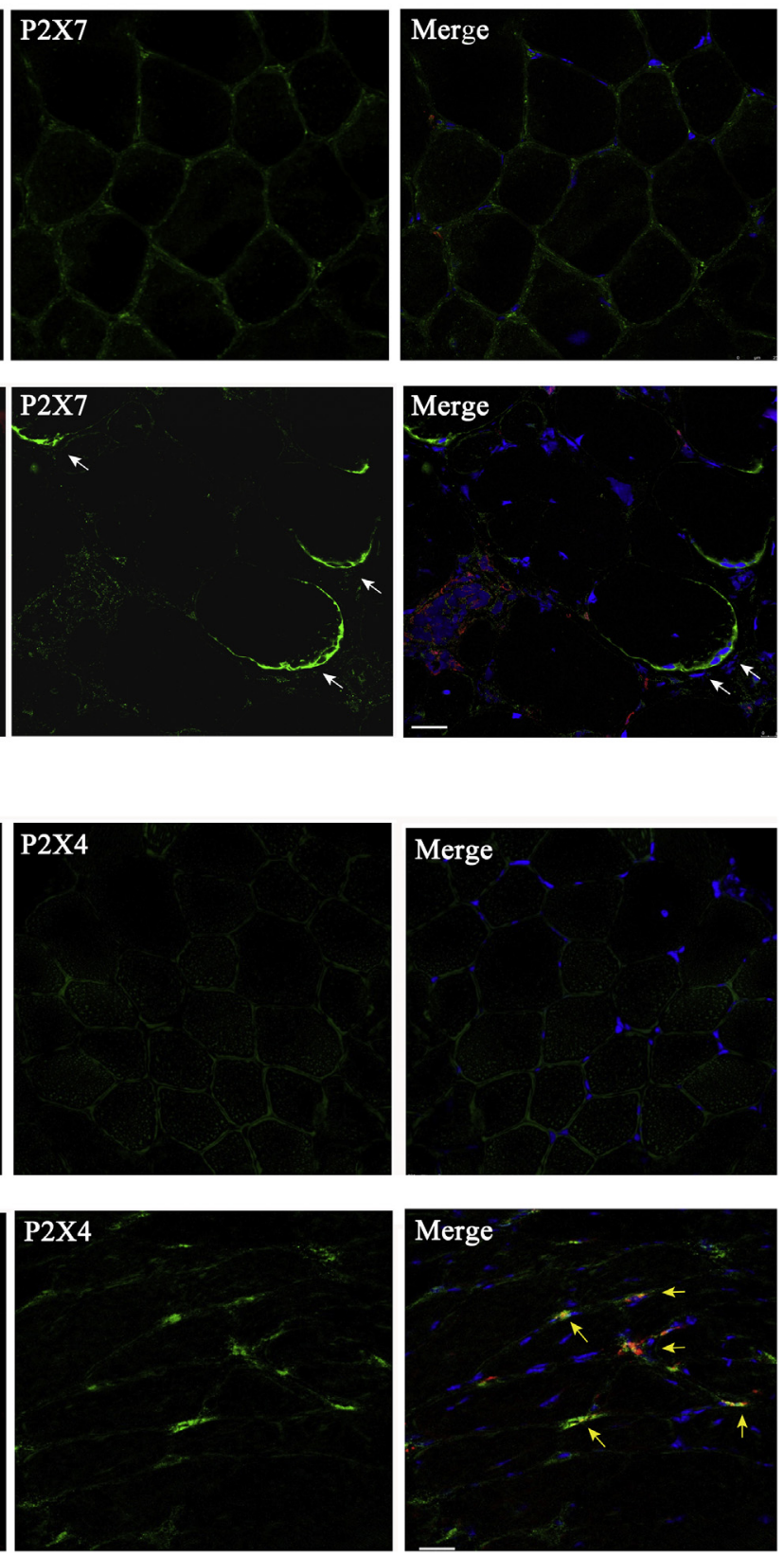

Figure 4 P2X7R is overexpressed in Sgca muscle cells, whereas P2X4R is mainly expressed in CD45 cells. A: Frozen muscle tissue sections of gastrocnemii (GN) from Sgca and WT mice were immunostained with a monoclonal anti-CD45 antibody (red) and a monoclonal P2X7R antibody (red). Representative images are shown. White arrows indicate examples of the positive cells for P2X7R. B: Frozen muscle tissue sections of GN from Sgca and WT mice were immunostained with a monoclonal anti-CD45 antibody (red) and a monoclonal P2X4R antibody (red). Representative images are shown. Yellow arrows indicate examples of the positive cells for P2X4R and CD45. $n=4$ (A and B, Sgca and WT mice). Scale bar $=25 \mu \mathrm{m}$ (A and B). Original magnification, $\times 40$ (A and B).

were up-regulated by 7.5-, 4.1-, and 10-fold, respectively. ${ }^{17}$ CD3 transcripts were increased by 3 -fold, with a 10 foldincrease of the proportion of CD4-expressing lymphocytes, and a 30\% reduction in CD8A mRNA levels. Moreover, CD4 induction was associated with a 1.8 -fold up-regulation of FOXP3, a marker of $\mathrm{CD}^{+}{ }^{+}$T-regulatory (Treg) cells.

The recruitment of immune cells in the muscle of Sgca mice was confirmed by a 4.7-, 1.8-, and 11-fold induction of the proinflammatory cytokines IL- $1 \beta$, IFN- $\gamma$, and IL-6, respectively, but also by a 50- and 3-fold induction of the Treg-specific anti-inflammatory cytokine IL-10 and of the Treg-secreted growth factor amphiregulin, respectively (Figure 1).

Sgca Primary Myotubes Are Characterized by a Defect in Ecto-ATPase Activity and Undergo Apoptosis on ATP Treatment

Primary satellite cells were isolated from the forelimb, hind limb, and diaphragm muscles of passage 8 to passage 10 old Sgca and WT mice and cultured until they completely 

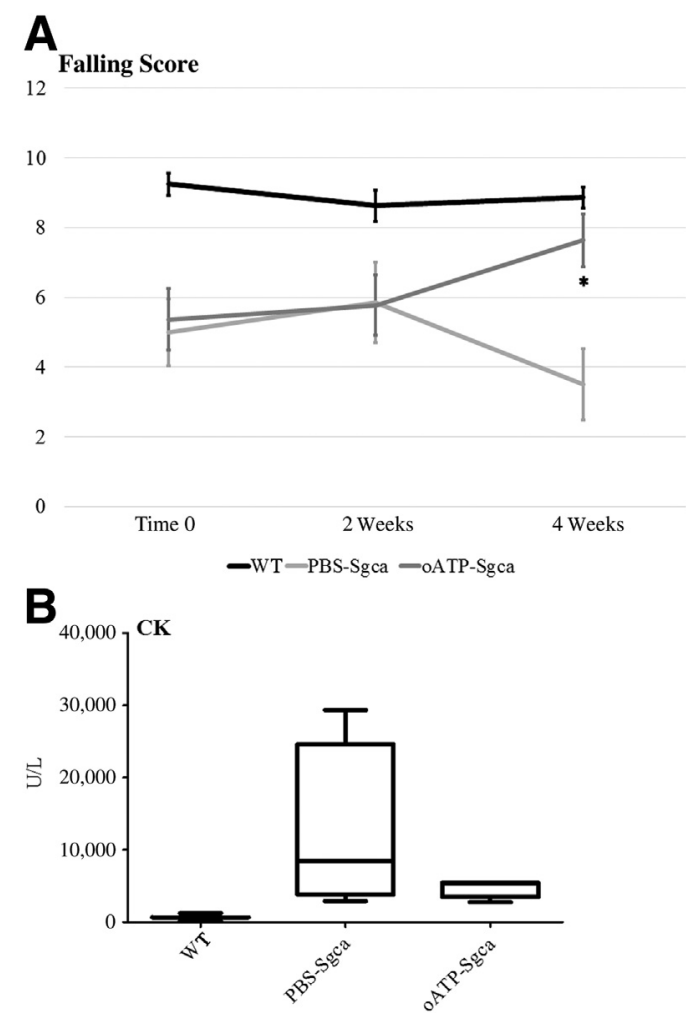

Figure 5 OATP improves muscle strength and ameliorates creatine kinase (CK) serum levels in Sgca mice. A: Four-limb hanging test was performed on PBS-Sgca (light gray line), oATP-Sgca (dark gray line), and age-matched WT controls (black line) at the beginning and at the end of the second and fourth week of treatment. B: Serum CK levels were evaluated at the end of the fourth week of treatment. Blood samples were obtained via cardiac puncture from PBS-Sgca, oATP-Sgca, and WT mice. Data are expressed as medians \pm first and third quartiles. WT $=675$ (130 to 1220), PBSSgca $=8460$ (3835 to 24,635), oATP-Sgca $=5360$ (3500 to 5440). Statistical analysis was performed using the $U$-test. Data are expressed as means \pm SD (A). $n=12$ animals $(\mathbf{A}) ; n=10$ animals for each experimental group (B). ${ }^{*} P<0.05$ for oATP-treated mice versus PBS-treated mice.

differentiated into mature myotubes. The absence of expression of $\alpha$-SG was confirmed by Western blot analysis on total cellular extracts. Sgca-deficient cells displayed normal levels of caveolin-3 and myosin heavy chain, thus indicating the achievement of a functional muscle cell phenotype. The decrease observed in $\beta$-dystroglycan levels is in accordance with the disruption of the dystrophin-glycoprotein complex in $\alpha$-sarcoglycanopathies (Figure 2A).

The ecto-ATPase activity was quantified by measuring ATP metabolism in mass spectrometry, in WT and Sgca cells switched to a basal medium containing ATP at $0.3 \mathrm{mmol} / \mathrm{L}$. When compared with the WT, Sgca cells were characterized by decreased ecto-ATPase activity (Figure 2B), resulting in increased ATP levels in culture medium. Muscle cells express the ecto-ATPase CD39, which converts ATP to ADP. However, the increase in ATP levels observed in the Sgca group appeared to be specifically related to the absence of the $\alpha$-SG ecto-ATPase activity because the protein levels of CD39 were not modified between Sgca and WT muscle lysates (Figure 2C).
For the evaluation of apoptosis, the cells were pretreated with $1 \mu \mathrm{g} / \mathrm{mL}$ LPS for 4 hours, incubated with $3 \mathrm{mmol} / \mathrm{L}$ ATP and $300 \mu \mathrm{mol} / \mathrm{L}$ BzATP for 16 hours, and then stained with the Annexin A5 FITC/7-AAD Kit. The feasibility of a citofluorimetric assay in myotubes has been previously determined. ${ }^{14-16}$ The number of apoptotic muscle cells was determined measuring the percentage of Annexin $\mathrm{V}^{+} / 7$ $\mathrm{AAD}^{-}$and Annexin $\mathrm{V}^{+} / 7-\mathrm{AAD}^{+}$cells (early and late apoptosis, respectively). The pretreatment with LPS is supported by the observation that LPS caused a marked upregulation of striatal P2X7 expression. ${ }^{18}$ ATP and, more potently, BzATP induced apoptosis, an effect that was further enhanced by a pretreatment with LPS (Figure 2D).

\section{P2XR Is Expressed in Sgca Muscle Tissue}

The pattern of expression of the P2XR was evaluated in muscle lysates from the GN of Sgca mice and age-matched WT controls. A specific up-regulation of P2X4R and P2X7R transcripts (sixfold and fourfold, respectively) was observed (Figure 3), whereas P2X2R transcript levels were not measurable (Figure 3). To determine whether P2X4R and P2XR7 were expressed in myofibers or in infiltrating inflammatory cells, a coimmunostaining was completed with the pan-granulocyte marker C45 and P2X4 and P2X7R antibodies, respectively, in GN sections.

P2X4R was hardly detectable on the muscle cell membrane in WT mice, and it was up-regulated and colocalized with CD45-positive cells in the Sgca mutants (Figure 4A). $\mathrm{P} 2 \mathrm{X} 7 \mathrm{R}$ expression was weak in WT myofibers, whereas clear and specific P2X7R patches at the plasma membrane level were detected in Sgca muscle fibers, suggesting an induction and a higher functionality of the receptor because of its cell surface localization. This same feature has been previously shown in the monocytic subset of myeloidderived suppressor cells isolated from tumor-bearing mice $^{19}$ (Figure 4B).

Targeting P2X Signaling in Vivo Improves Biochemical and Functional Parameters of Disease Progression in Sgca Mice

Given the representation of different P2XR in Sgca muscles, we aimed at initially achieving a pleiotropic antagonistic effect on eATP signaling cascade. Four-week-old Sgca mice were treated with oATP, a compound known to act on multiple P2X receptor molecules. OATP was administered via i.p. injections, at the dose of $6 \mathrm{mmol} / \mathrm{L}$. Sgca mice injected with vehicle alone (PBS) and a group of age- and sex-matched WT C57B1/6 mice served as controls. Mice were weighted at the beginning (baseline) of the treatment and then on a weekly basis. No significant difference was detected between the various groups (data not shown). The evaluation of muscle strength was completed by the fourlimb hanging test at the beginning of the treatment (time 0 ) and at the end of the second and fourth weeks of treatment. 
A

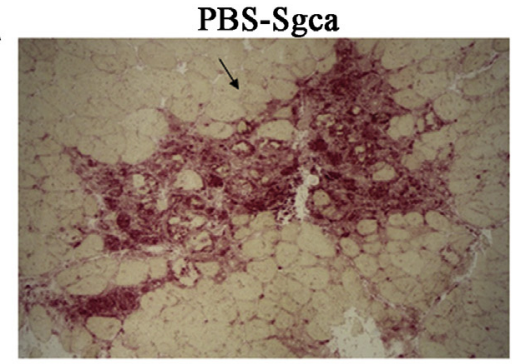

B

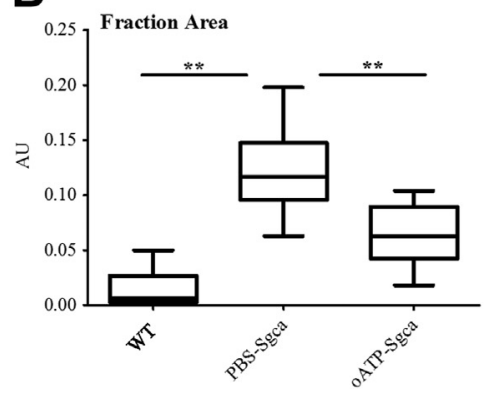

C

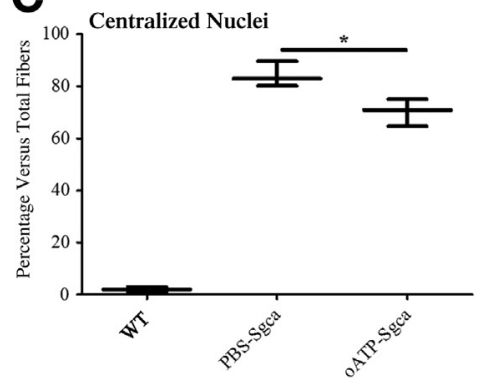

oATP-Sgca
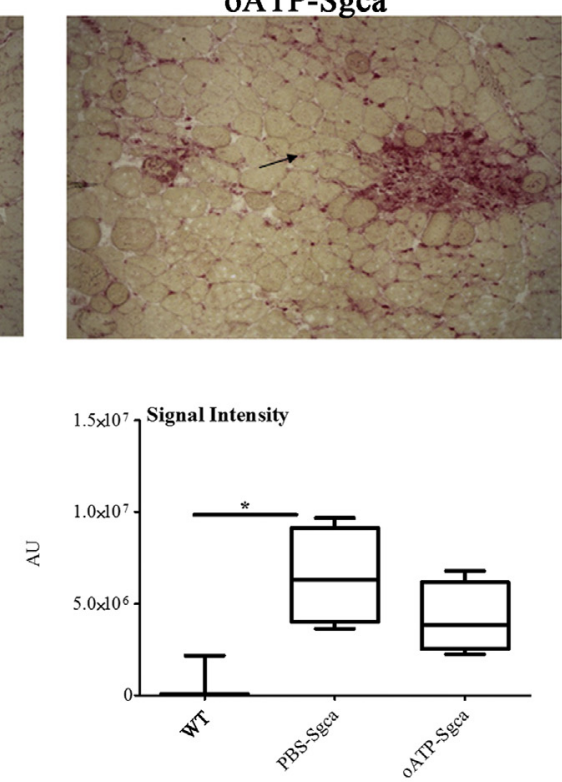

D

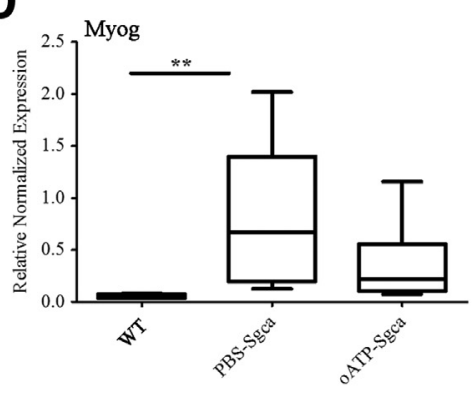

Figure 6 OATP improves the extension of reactive inflammatory infiltrates and morphologic features in Sgca mice. A: Frozen muscle tissue sections of gastrocnemii (GN) from PBS-Sgca and OATP-Sgca mice were collected at the fourth week of treatment and stained with acid phosphatase. Black arrows indicate inflammatory infiltrates. Representative images are shown. B: Graph of the analysis of the fraction areas and intensities of inflammatory infiltrates/total section area of muscles represented in $\mathbf{A}$. Data are expressed as medians \pm first and third quartiles. Area: WT $=0.006$ (0.002 to 0.0267), PBS-Sgca $=0.117$ (0.09 to 0.14), oATP-Sgca $=0.063$ (0.04 to 0.09). Signal intensity: $W T=71,886(12,400$ to $217,000)$, PBS-Sgca $=6.30 \times 10^{6}\left(4.01 \times 10^{6}\right.$ to 9.12 $\left.\times 10^{6}\right)$, oATP-Sgca $=3.85 \times 10^{6}\left(2.53 \times 10^{6}\right.$ to $6.13 \times$ $\left.10^{6}\right)$. Statistical analysis was performed using the $U$-test. C: The number of central nuclei was quantified in 600 fibers of three consecutive fields for each muscle section stained with hematoxylin and eosin. Data are expressed as medians \pm first and third quartiles. WT $=2.00$ (1.00 to 3.00$)$, PBS-Sgca $=82.91$ (80.18 to 89.34 ), oATPSgca $=70.89$ (64.76 to 75.01). Statistical analysis was performed using the $U$-test. D: Total RNA isolated from GN lysates from PBS-Sgca, oATP-Sgca, and WT agematched controls was reverse transcribed. Myogenin transcripts (Myog) were quantified by real-time quantitative PCR. Ppia and Rpl13a served as housekeeping genes. Data are expressed as medians \pm first and third quartiles. WT $=0.054$ (0.037 to 0.076), PBSSgca $=0.669(0.19-1.39)$, oATP-Sgca $=0.217$ (0.10 to $0.55)$. Statistical analysis was performed using the $U$ test. $n=10$ (A, PBS-Sgca and oATP-Sgca mice, C, mice for each experimental group, and D, PBS-Sgca, oATPSgca, and WT mice). ${ }^{*} P<0.05,{ }^{*} P<0.01$. Original magnification, $\times 10($ A). . AU, arbitrary unit.
As expected from the literature, the untreated Sgca group displayed a progressive worsening of muscle strength along time, whereas the oATP-Sgca cohort maintained the scores measured at time $0(P<0.05$ for oATP-treated mice versus PBS-treated mice after 4 weeks) (Figure 5A).

Serum creatine kinase concentrations, a marker of muscle cell degeneration, were evaluated at the end of the trial by cardiac puncture. Creatine kinase was markedly increased in PBS-Sgca mice when compared with the WT cohort, whereas the treatment with the P2X antagonist led to a $35 \%$ decrease of this effect (Figure 5B).

\section{Inhibition of P2X Signaling Ameliorates Morphologic Features and Reduces the Amplitude of the Innate and Adaptive Immune Responses in Sgca Mice}

The fraction area and the intensity of the inflammatory reactions surrounding degenerative/necrotic muscle cells were evaluated in GN from PBS- and oATP-treated animals by acid phosphatase staining, which provides a red positive signal in activated macrophages and degenerative myofibers. These parameters were decreased in the oATP-treated group by $46 \%$ and $38 \%$, respectively $(P<0.01$ and $P<0.05$, respectively) (Figure 6, A and B).
Muscle morphology was quantified in GN by standard hematoxylin and eosin staining. Central nucleation (percentage), a sign of dystrophic myopathic damage, was reduced by $14 \%$ in GN of oATP-treated animals (Figure 6C). Moreover, muscle tissue from untreated Sgca mutants, when compared with WT mice, displayed an increase of myogenin transcripts, a muscle-specific transcription factor expressed by committed myoblasts in regeneration and typically upregulated in the degenerative/regenerative cell cycles of active muscular dystrophies. This effect was blunted by $67 \%$ after oATP treatment, thus suggesting an inhibition of degenerative cellular events (Figure 6D).

In diaphragms, P2X antagonism resulted in a $71 \%$ and $11 \%$ decrease in the areas and number of the inflammatory reactions surrounding the muscle cells in necrosis, respectively (hematoxylin and eosin staining). The beneficial effect of purinergic antagonism was associated also with a $16 \%$ reduction of centralized nuclei $(P<0.05)$ (Supplemental Figure S1).

Immunostaining and measurement of the $\mathrm{CD} 45^{+}$and Ly6C $\mathrm{C}^{+}$leukocytes infiltrating the muscle tissue revealed a positive signal for both markers in different sites of the inflammatory responses surrounding necrotic fibers. When quantified by automated microscopy on the total section area, the number of $\mathrm{CD}_{4} 5^{+}$and $\mathrm{Ly} 6 \mathrm{C}^{+}$cells in the total 

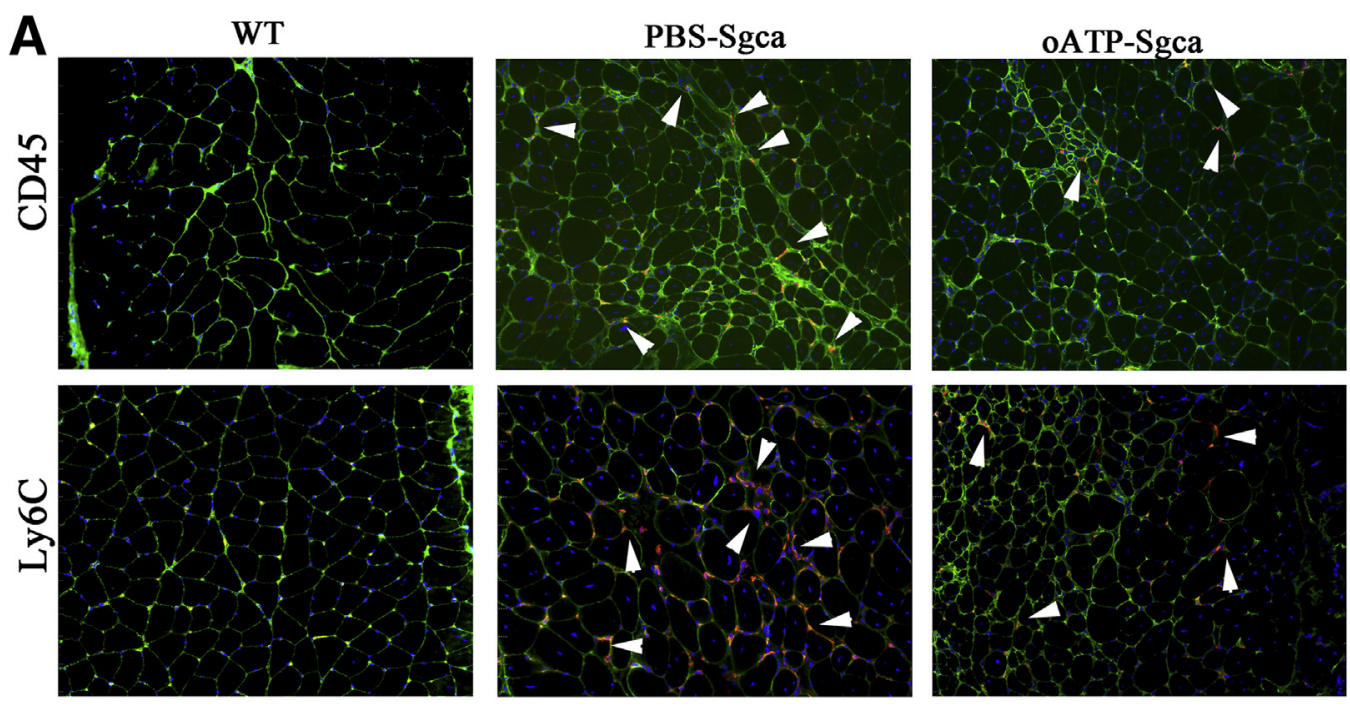

B

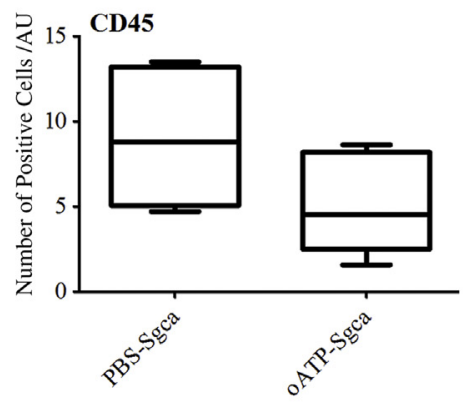

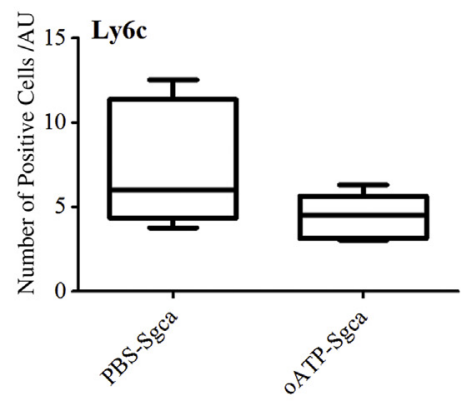

C
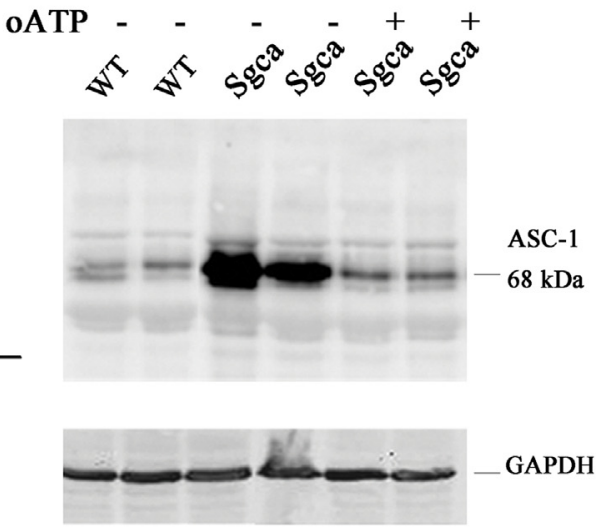

Figure 7 OATP induces a decrease of inflammatory cytokines and monocyte infiltration in muscles from Sgca mice. A: Frozen muscle tissue sections of gastrocnemii (GN) from PBS-Sgca and oATP-Sgca mice were collected at the fourth week of treatment and immunostained with a monoclonal anti-CD45 antibody (red), monoclonal anti-Ly6C antibody (red), and monoclonal anti-caveolin-3 antibody (green). Representative images are shown. White arrowheads indicate examples of the positive cells for CD45 and Ly6C markers. B: Graph of the number of CD45 ${ }^{+}$, Ly6C ${ }^{+}$cells/arbitrary unit (AU) of total section area of muscles represented in A. Data are expressed as medians \pm first and third quartiles. CD45: PBS-Sgca $=8.80$ (5.06 to 13.22), oATP-Sgca $=4.54$ (2.51 to 8.18). Ly6C: PBS-Sgca $=6.02$ (4.35 to 11.36), oATP-Sgca $=4.51$ (3.14 to 5.64). Statistical analysis was performed using the U-test. C: Total protein lysates, isolated from GN of oATP-treated Sgca $\left(\right.$ oATP $\left.^{+}\right)$, untreated Sgca (oATP ${ }^{-}$, and WT age-matched controls, were subjected to Western blot analysis. Membranes were probed with a mouse monoclonal anti-activating signal cointegrator-1 (ASC-1) antibody. Samples were run in triplicate. Representative images are shown. $n=10$ (A, PBS-Sgca and oATP-Sgca mice). Original magnification, $\times 20$ (A). GAPDH, glyceraldehyde-3-phosphate dehydrogenase.

areas was inhibited by $45 \%$ and $25 \%$, respectively, in oATP-treated mice (Figure 7, A and B).

Accordingly, the protein levels of ASC-1, a coactivator of $\mathrm{NF}-\kappa \beta$, were undetectable in WT mice, markedly increased in Sgca muscle lysates, and significantly inhibited after P2X blockade (Figure 7C).

The immunostaining and measurement of the CD3 lymphocytes infiltrating the muscle tissue showed a CD3-positive signal in different sites of reactive inflammatory responses. When quantified by automated microscopy on the total section area, the fraction areas of CD3-positive signal were reduced by $52 \%$ in oATP-treated mice (data not shown).

Despite the decrease in the total number of CD3-positive cells, $\mathrm{FOXP}^{+}$cells were increased in muscle tissue of oATP-treated Sgca mutants by $34 \%$ (Figure 8, A and B).
The mechanisms of how oATP affects innate and adaptive response in Sgca skeletal muscle were also investigated by quantification of muscular IL- $1 \beta$, IL- 6 , and IFN- $\gamma$ transcripts. When compared with the PBS cohort, these cytokines were reduced by $49 \%, 39 \%$, and $44 \%$, respectively, in the oATP group (Figure 8C).

\section{Targeting P2X Signaling in Vivo Decreases Muscular} Fibrotic Degeneration, Reducing the Transcription of Muscle Profibrotic Factors in Sgca Mice

In accordance with this anti-inflammatory image, P2X blockade led to a reduction of the transcription of fibrogenic factors, which ultimately stimulate endomysial fibrosis and connective replacement of muscle tissue. The transcripts of 

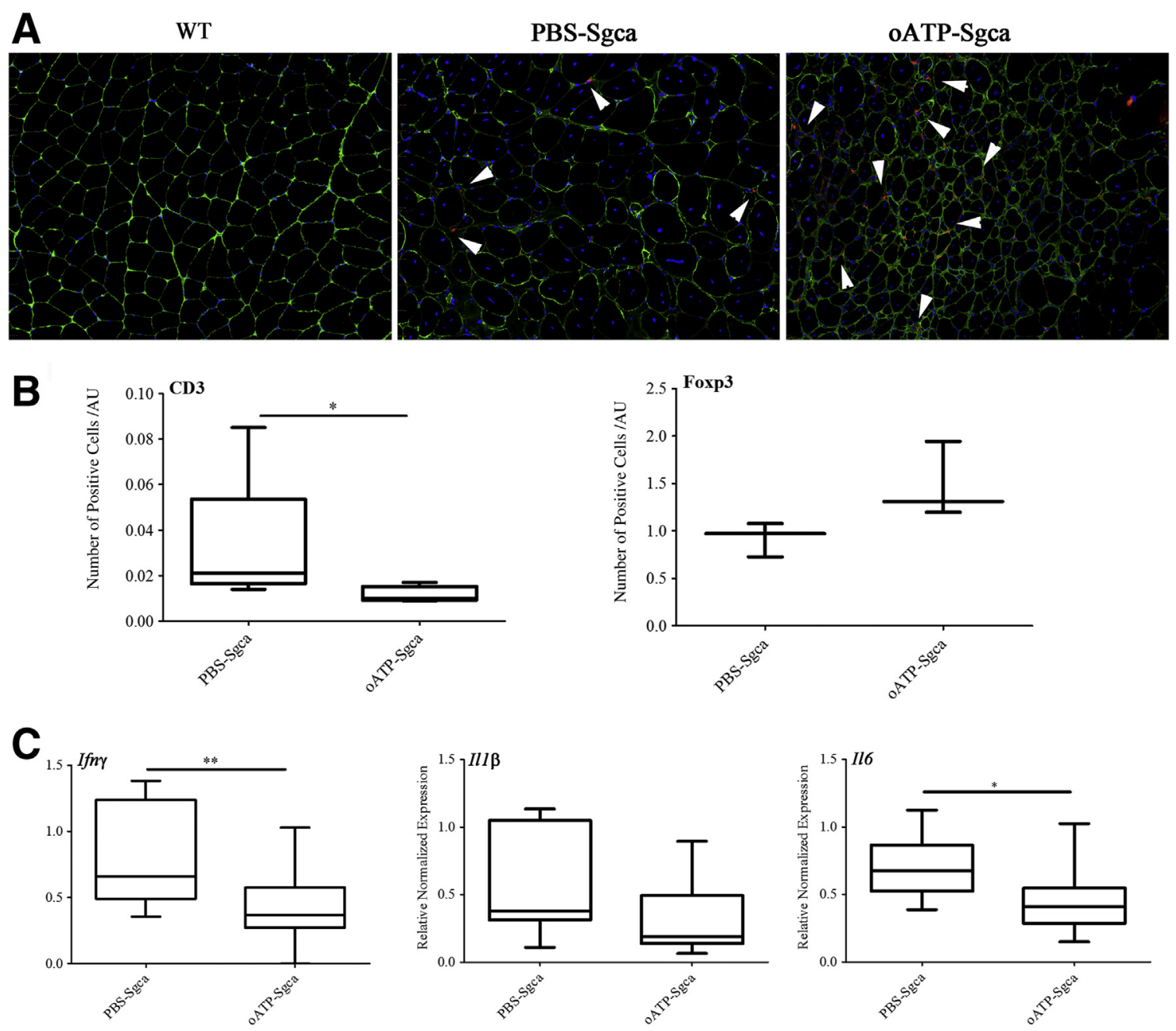

Figure 8 OATP decreases the total number of $\mathrm{CD}^{+}$lymphocytes but increases the extension of forkhead box protein P3 (Foxp3)-positive cells in Sgca mice. A: Frozen muscle tissue sections of gastrocnemii (GN) from PBS-Sgca and oATP-Sgca mice were collected at the fourth week of treatment and immunostained with a monoclonal anti-FOXP3 antibody. White arrowheads indicate FOXP3 ${ }^{+}$cells. Representative images are shown. B. Graph of the number of $\mathrm{CD}^{+}$and $\mathrm{FOXP}^{+}$cells/arbitrary unit (AU) of total section area of muscles represented in $\mathbf{A}$. Data are expressed as medians \pm first and third quartilesPBS-Sgca $=0.971$ (0.72 to 1.07), oATP-Sgca $=1.308$ (1.19 to 1.94). Statistical analysis was performed using the U-test. C: Total RNA isolated from GN lysates from PBS-Sgca and oATP-Sgca mice was reverse transcribed. IL-1 $\beta$, IL-6, and interferon (IFN)- $\gamma$ transcripts were quantified by real-time quantitative PCR. Ppia and Rpl13a served as housekeeping genes. Data are expressed as medians \pm first and third quartilesIL-1 $\beta$ : PBSSgca $=0.378$ (0.311 to 1.04$)$, oATP-Sgca $=0.190$ (0.13 to 0.49). IL-6: PBS-Sgca $=0.674$ (0.52 to 0.86); oATP-Sgca $=0.409$ (0.28 to 0.54$)$. IFN- $\gamma$ : PBS-Sgca $=0.660$ (0.49 to 1.23), oATP-Sgca $=0.367$ (0.27 to 0.57). Statistical analysis was performed using the $U$-test. $n=10$ (A and C, PBS-Sgca and oATP-Sgca mice). ${ }^{*} P<0.05,{ }^{* *} P<0.01$. Original magnification, $\times 20(\mathbf{A})$.

osteopontin (secreted phosphorylated protein 1), connective tissue growth factor, and TGF- $\beta 1$ were quantified in total muscle lysates isolated from the GN of WT, PBS-treated, and oATP-treated Sgca mice and displayed a $79 \%, 45 \%$, and $77 \%$ reduction in the presence of eATP blockade, respectively (Figure 9).

The effects of oATP on collagen type I and on TGF- $\beta$ were also confirmed at the protein levels. P2X antagonism prevented the up-regulation of collagen type I observed in the untreated cohort, and it led to a reduction of both dimeric $(25 \mathrm{kDa})$ and monomeric $(15 \mathrm{kDa})$ active TGF- $\beta$ isoforms (Figure 10A).

Accordingly, histologic analyses by Masson trichrome staining on GN sections revealed that oATP treatment led to a 20\% decrease of the fraction area (Figure 10, B and C). Staining with Picrosirius red in diaphragms corroborated a $40 \%$ and $43 \%$ decrease of the fraction area and the intensity of fibrotic tissue in the oATP-treated group, respectively (Supplemental Figure S2).

\section{Discussion}

In sarcoglycanopathies, the mechanically weaker plasma membrane is easily damaged during muscle contraction, allowing release of intracellular antigens, infiltration of immune cells, and induction of profibrotic cytokines and growth factors. ${ }^{3}$ Although different experimental models 


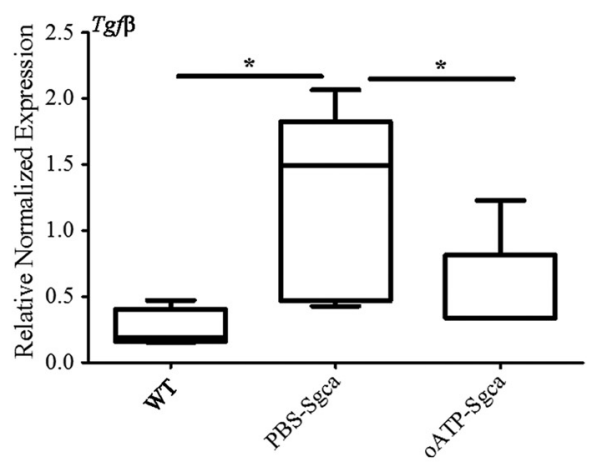

tissue. $^{21-25}$ Type 1 inflammation is characterized by increased expression of IFN- $\gamma$ and is counterregulated by type 2 cytokines, such as IL-4 and IL-13, and the Treg anti-inflammatory cytokine IL-10.

Herein, it was found that type 1 and type 2 inflammation are activated also in $\alpha$-SG deficiency. When compared with WT animals, $\alpha$-SG-deficient muscle tissue displayed higher expression levels of proinflammatory cytokines, such as IL-1 $\beta$, IFN- $\gamma$, and IL-6, augmented content of the proinflammatory molecule ASC-1, and increased infiltration of CD45 leukocytes, macrophages (innate immunity), and $\mathrm{CD}^{+}$lymphocytes (adaptive immunity). This process was counteracted by an increase in the number of $\mathrm{FOXP}^{+}$ $\mathrm{CD} 4^{+}$Tregs, which also showed an activated phenotype, as confirmed by induced levels of the cytokine IL-10.

The potential role of the DAMP molecule eATP was next studied in the development of this tissue-specific immunemediated damage, and it was shown, for the first time, that $\mathrm{P} 2 \mathrm{X}$-purinergic signaling is involved in this pathologic cascade.

Sgca mice were characterized by an enhanced expression of $\mathrm{P} 2 \mathrm{X} 4$ and $\mathrm{P} 2 \mathrm{X} 7$ receptors in muscle tissue, confirming that SG defects, as dystrophinopathies, result into a purinergic pathway overactivation. Although P2X4R was mainly up-regulated in $\mathrm{CD}_{4} 5^{+}$inflammatory cells infiltrating the muscle, P2X7R was overexpressed on the plasma membrane of Sgca muscle fibers. Noteworthy, in dystrophic cells, the receptor molecules were found to be organized in specific patches, suggesting in the monocytic subset of myeloidderived suppressor cells isolated from tumor-bearing mice. ${ }^{19}$

An excess of ATP in the extracellular milieu can be counteracted by the action of the ecto-ATPases CD39 and CD73, which in subsequential order convert ATP to adenosine. However, also, $\alpha$-SG displays in its C-terminal domain an ecto-ATPase function, and its absence causes a more consistent accumulation of ATP in the culture medium of primary myotubes. In turn, as already shown in distinct cell systems, an excessive extracellular ATP stimulation is able to exert a direct toxic effect in muscle cells because it induces apoptosis. $^{26,27}$ The molecular basis of the proapoptotic effect can be because of an effect on mitochondrial metabolism or the association with pannexin molecules and the formation of a cytolytic pore (ie, a large conductance channel).

According to these first observations, the pharmacologic inhibition of purinergic signaling via oATP led to an improvement of muscular function and structure, a reduction of the innate/adaptive immune response and fibrosis, and an increase in $\mathrm{FOXP}^{+} \mathrm{CD}^{+}$Treg muscle infiltration. In this scenario, it is likely that the oATP-mediated boosting of Treg muscle infiltration played a role in ameliorating the Sgca mice phenotype. It has been shown that skeletal muscle resident Treg, producing IL-10 and expressing Areg, controls the switch of type 1 to type 2 inflammation in injured muscle and acts directly on muscle satellite cells, improving muscle repair. $^{28-30}$ Noteworthy, myoblasts 

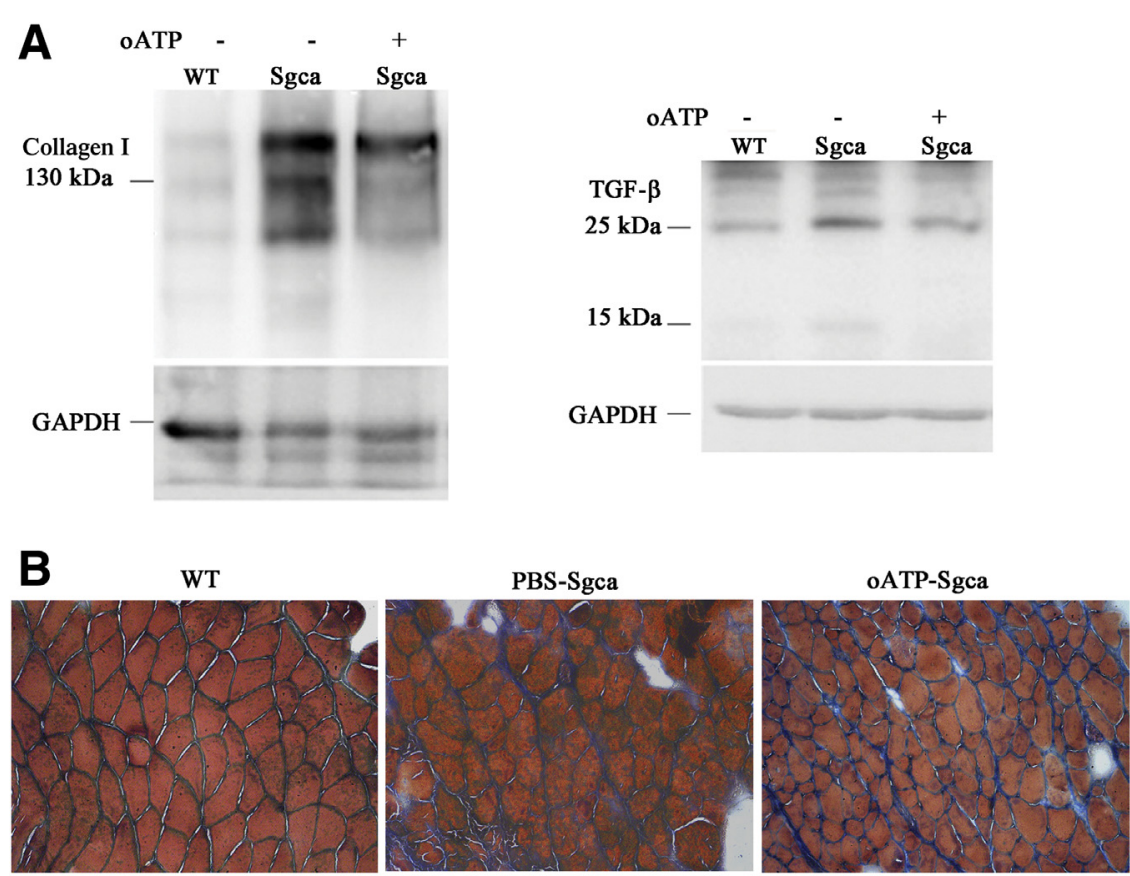

Figure 10 OATP induces a decrease of collagen profibrotic factors in muscles from Sgca mice. A: Total protein lysates, isolated from gastrocnemii (GN) of PBS-Sgca, OATP-Sgca, and WT age-matched controls, were subjected to Western blot analysis. Membranes were probed with a rabbit polyclonal anti-collagen type I and a mouse monoclonal anti -transforming growth factor- $\beta$ (TGF- $\beta$; the $25-\mathrm{kDa}$ dimer and the $15-\mathrm{kDa}$ monomer) antibody. Representative images are shown. B: Frozen muscle tissue sections of GN from PBS-Sgca, oATPSgca, and WT age-matched controls were collected at the fourth week of treatment and stained with a standard Masson trichrome stain protocol. Representative images are shown. C: Graph of the fraction areas of fibrotic blue positive signal/arbitrary unit (AU) of total section area of muscles represented in B. Data are expressed as medians \pm first and third quartiles. WT $=0.029$ (0.026-0-031), PBS-Sgca $=0.077(0.076$ to 0.107$)$, oATPSgca $=0.061$ (0.052 to 0.067). Statistical anal-

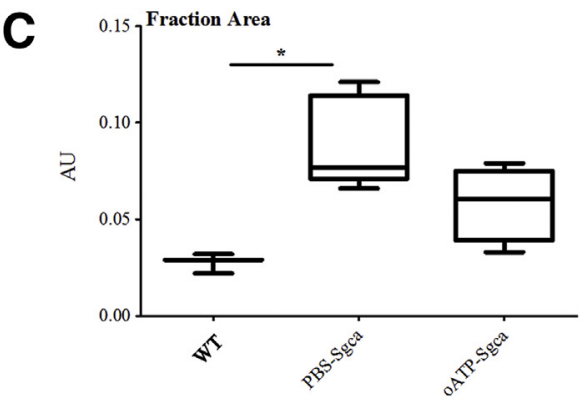
ysis was performed using the U-test. $n=6(\mathbf{A}$, PBS-Sgca, oATP-Sgca, and WT mice); $n=5$ (B, PBS-Sgca, OATP-Sgca, and WT mice). ${ }^{*} P<0.05$ for WT versus Sgca. Original magnification, $\times 10$ (B). GAPDH, glyceraldehyde-3-phosphate dehydrogenase.

isolated from $m d x$ mice showed an increased cytosolic $\mathrm{Ca}^{2+}$ ion influx and IL- $1 \beta$ release when stimulated with BzATP, ${ }^{31}$ thus evoking an active role of skeletal muscle cells in the inflammatory mechanism through P2X-purinergic signaling. The assessment of Sgca and LGMD2D primary myoblast behavior under eATP stimulation and the direct effect of P2XR inhibition on these cells will be evaluated in our future studies.

oATP was originally described as an irreversible P2X7R antagonist ${ }^{32}$ but was shown later to also block other P2XRs, such as the P2X4 subtype, ${ }^{33}$ making this compound a good candidate for a first proof of principle of our hypothesis in Sgca mice, in which an up-regulation of both P2X7 and P2X4 receptors was found. oATP has also demonstrated promise as a treatment modality in several models of autoimmune diseases. Successful examples are experimental models of collagen-induced arthritis, autoimmune diabetes, allergic encephalitis, autoimmune colitis, and allograft rejection in cardiac and islet transplantation. ${ }^{33-39}$ In these disorders, the compound works as a suppressor of the innate and adaptive immunity as well as an inductor of Treg expansion.
However, numerous other P2XR antagonists, more efficient and more specific, have been discovered in the past few years, especially anti-P2X7R. ${ }^{40-43}$ CE-224,535 has been tested in clinical trials for rheumatoid arthritis in patients with an inadequate response to methotrexate. The drug was not efficacious, compared with placebo, but demonstrated an acceptable safety and tolerability profile (NCT00628095). ${ }^{44,45}$ The purinergic P2X7 antagonist AZD9056 was shown to have the potential to improve symptoms in patients with moderate-to-severe Crohn disease combined with a beneficial risk profile. AZD9056 was well tolerated, and no serious adverse events were reported. ${ }^{46}$ The molecule GSK1482160 has already been explored as a possible tool to detect neuroinflammation, and a phase I clinical study in humans is currently undergoing (NCT00849134). ${ }^{47}$

Currently, no therapies are available for LGMD2D patients. Many studies in each of the four sarcoglycan deficiencies demonstrated that viral-mediated gene transfer, using adeno-associated vectors, can correct the pathologic signs of the disease in animal models. ${ }^{48-56}$ However, some previous $\alpha$-SG gene transfer experiments revealed the 
occurrence of specific immune response, leading to generation of $\alpha-S G-$ specific antibody, T-cell infiltration of treated muscles, and disappearance of the vector. In this respect, we suggest that $\mathrm{P} 2 \mathrm{X}$-purinergic signal antagonism, with its double anti-inflammatory effect (inhibition of innate/adaptive inflammatory response and enhancement of immune tolerance by Treg expansion), could be associated with gene transfer therapies for the treatment of LGMD2D to obtain a more stable $\alpha$-SG expression.

Moreover, this study is in agreement with recent lines of research, which emphasize the relevance of DAMPs in chronic degenerative disorders. Intriguingly, these sophisticated molecules are danger signals important not only for the inflammatory response but also for tissue repair because they can orchestrate tissue healing by acting on different receptors. Thus, better understanding of the consequences of DAMP signaling on muscle inflammation and on muscle regeneration is the key to promote tissue repair and healing.

\section{Acknowledgment}

We thank Prof. Giulio Cossu for donating Sgca mice.

\section{Supplemental Data}

Supplemental material for this article can be found at https://doi.org/10.1016/j.ajpath.2018.10.008.

\section{References}

1. Vainzof M, Passos-Bueno MR, Pavanello RC, Marie SK, Oliveira AS, Zatz M: Sarcoglycanopathies are responsible for $68 \%$ of severe autosomal recessive limb-girdle muscular dystrophy in the Brazilian population. J Neurol Sci 1999, 164:44-49

2. Angelini C, Fanin M, Freda MP, Duggan DJ, Siciliano G, Hoffman EP: The clinical spectrum of sarcoglycanopathies. Neurology 1999, 52:176-179

3. Kirschner J, Lochmuller H: Sarcoglycanopathies. Handb Clin Neurol 2011, 101:41-46

4. Rubartelli A, Lotze MT: Inside, outside, upside down: damage-associated molecular-pattern molecules (DAMPs) and redox. Trends Immunol 2007, 28:429-436

5. Bours MJ, Swennen EL, Di Virgilio F, Cronstein BN, Dagnelie PC: Adenosine 5'-triphosphate and adenosine as endogenous signaling molecules in immunity and inflammation. Pharmacol Ther 2006, 112: 358-404

6. Willart MA, Lambrecht BN: The danger within: endogenous danger signals, atopy and asthma. Clin Exp Allergy 2009, 39:12-19

7. Khakh BS, North RA: P2X receptors as cell-surface ATP sensors in health and disease. Nature 2006, 442:527-532

8. Gazzerro E, Baldassari S, Assereto S, Fruscione F, Pistorio A, Panicucci C, Volpi S, Perruzza L, Fiorillo C, Minetti C, Traggiai E, Grassi F, Bruno C: Enhancement of muscle T regulatory cells and improvement of muscular dystrophic process in $\mathrm{mdx}$ mice by blockade of extracellular ATP/P2X axis. Am J Pathol 2015, 185: $3349-3360$

9. Sinadinos A, Young CN, Al-Khalidi R, Teti A, Kalinski P, Mohamad S, Floriot L, Henry T, Tozzi G, Jiang T, Wurtz O, Lefebvre A, Shugay M, Tong J, Vaudry D, Arkle S, doRego JC, Górecki DC: P2RX7 purinoceptor: a therapeutic target for ameliorating the symptoms of Duchenne muscular dystrophy. PLoS Med 2015, 12:e1001888

10. Betto R, Senter L, Ceoldo S, Tarricone E, Biral D, Salviati G: EctoATPase activity of alpha-sarcoglycan (adhalin). J Biol Chem 1999, 274:7907-7912

11. Sandonà $\mathrm{D}$, Gastaldello $\mathrm{S}$, Martinello $\mathrm{T}$, Betto R: Characterization of the ATP-hydrolyzing activity of alpha-sarcoglycan. Biochem J 2004, 381:105-112

12. Gazzerro E, Assereto S, Bonetto A, Sotgia F, Scarfî S, Pistorio A, Bonuccelli G, Cilli M, Bruno C, Zara F, Lisanti MP, Minetti C: Therapeutic potential of proteasome inhibition in Duchenne and Becker muscular dystrophies. Am J Pathol 2010, 176:1863-1877

13. Grozio A, Sociali G, Sturla L, Caffa I, Soncini D, Salis A, Raffaelli N, De Flora A, Nencioni A, Bruzzone S: CD73 protein as a source of extracellular precursors for sustained NAD+ biosynthesis in FK866treated tumor cells. J Biol Chem 2013, 288:25938-25949

14. Munoz J, Zhou Y, Jarrett HW: LG4-5 domains of laminin-211 binds alpha-dystroglycan to allow myotube attachment and prevent anoikis. J Cell Physiol 2010, 222:111

15. Muratore M, Srsen V, Waterfall M, Downes A, Pethig R: Biomarkerfree dielectrophoretic sorting of differentiating myoblast multipotent progenitor cells and their membrane analysis by Raman spectroscopy. Biomicrofluidics 2012, 6:034113

16. Pawlikowski B, Lee L, Zuo J, Kramer R: Analysis of human muscle stem cells reveals a differentiation-resistant progenitor cell population expressing Pax7 capable of self-renewal. Dev Dyn 2009, 238: $138-149$

17. Jablonski KA, Amici SA, Webb LM, Ruiz-Rosado JdD, Popovich PG, Partida-Sanchez S, Guerau-de-Arellano M: Novel markers to delineate murine M1 and M2 macrophages. PLoS One 2015, 10:e0145342

18. Choi HB, Ryu JK, Kim SU, McLarnon JG: Modulation of the purinergic P2X7 receptor attenuates lipopolysaccharide-mediated microglial activation and neuronal damage in inflamed brain. $\mathrm{J}$ Neurosci 2007, 27:4957-4968

19. Bianchi G, Vuerich M, Pellegatti P, Marimpietri D, Emionite L, Marigo I, Bronte V, Di Virgilio F, Pistoia V, Raffaghello L: ATP/P2X7 axis modulates myeloid-derived suppressor cell functions in neuroblastoma microenvironment. Cell Death Dis 2014, 5: e1135

20. Brunelli S, Sciorati C, D’Antona G, Innocenzi A, Covarello D, Galvez BG, Perrotta C, Monopoli A, Sanvito F, Bottinelli R, Ongini E, Cossu G, Clementi E: Nitric oxide release combined with nonsteroidal antiinflammatory activity prevents muscular dystrophy pathology and enhances stem cell therapy. Proc Natl Acad Sci U S A 2007, 104:264-269

21. De Paepe B, De Bleecker JL: Cytokines and chemokines as regulators of skeletal muscle inflammation: presenting the case of Duchenne muscular dystrophy. Mediators Inflamm 2013, 2013:540370

22. Saito K, Kobayashi D, Komatsu M, Yajima T, Yagihashi A, Ishikawa Y, Minami R, Watanabe N: A sensitive assay of tumor necrosis factor alpha in sera from Duchenne muscular dystrophy patients. Clin Chem 2000, 46:1703-1704

23. Evans NP, Misyak SA, Robertson JL, Bassaganya-Riera J, Grange RW: Immune-mediated mechanisms potentially regulate the disease time-course of Duchenne muscular dystrophy and provide targets for therapeutic intervention. PMR 2009, 1:755-768

24. De Pasquale L, D'Amico A, Verardo M, Petrini S, Bertini E, De Benedetti F: Increased muscle expression of interleukin-17 in Duchenne muscular dystrophy. Neurology 2012, 78:1309-1314

25. Rufo A, Del Fattore A, Capulli M, Carvello F, De Pasquale L, Ferrari S, Pierroz D, Morandi L, De Simone M, Rucci N, Bertini E, Bianchi ML, De Benedetti F, Teti A: Mechanisms inducing low bone density in Duchenne muscular dystrophy in mice and humans. J Bone Miner Res 2011, 26:1891-1903

26. Orioli E, De Marchi E, Giuliani AL, Adinolfi E: P2X7 receptor orchestrates multiple signalling pathways triggering inflammation, 
autophagy and metabolic/trophic responses. Curr Med Chem 2017, 24:2261-2275

27. Gulbransen BD, Bashashati M, Hirota SA, Gui X, Roberts JA, MacDonald JA, Muruve DA, McKay DM, Beck PL, Mawe GM, Thompson RJ, Sharkey KA: Activation of neuronal P2X7 receptorpannexin 1 mediates death of enteric neurons during colitis. Nat Med 2012, 18:600-604

28. Burzyn D, Kuswanto W, Kolodin D, Shadrach JL, Cerletti M, Jang Y, Sefik E, Tan TG, Wagers AJ, Benoist C, Mathis D: A special population of regulatory T cells potentiates muscle repair. Cell 2013, 155: $1282-1295$

29. Lei H, Schmidt-Bleek K, Dienelt A, Reinke P, Volk HD: Regulatory T cell-mediated anti-inflammatory effects promote successful tissue repair in both indirect and direct manners. Front Pharmacol 2015, 6:184

30. Schiaffino S, Pereira MG, Ciciliot S, Rovere-Querini P: Regulatory T cells and skeletal muscle regeneration. FEBS J 2017, 284:517-524

31. Rawat R, Cohen TV, Ampong B, Francia D, Henriques-Pons A, Hoffman EP, Nagaraju K: Inflammasome up-regulation and activation in dysferlin-deficient skeletal muscle. Am J Pathol 2010, 176: $2891-2900$

32. Murgia M, Hanau S, Pizzo P, Rippa M, Di Virgilio F, Oxidized ATP: An irreversible inhibitor of the macrophage purinergic $\mathrm{P} 2 \mathrm{Z}$ receptor. $\mathrm{J}$ Biol Chem 1993, 268:8199-8203

33. Di Virgilio F: Novel data point to a broader mechanism of action of oxidized ATP: the P2X7 receptor is not the only target. Br J Pharmacol 2003, 140:441-443

34. Ardissone V, Radaelli E, Zaratin P, Ardizzone M, Ladel C, Gattorno M, Martini A, Grassi F, Traggiai E: Pharmacologic P2X purinergic receptor antagonism in the treatment of collagen-induced arthritis. Arthritis Rheum 2011, 63:3323-3332

35. Lang PA, Merkler D, Funkner P, Funkner P, Shaabani N, Meryk A, Krings C, Barthuber C, Recher M, Brück W, Häussinger D, Ohashi PS, Lang KS: Oxidized ATP inhibits T-cell-mediated autoimmunity. Eur J Immunol 2010, 40:2401-2408

36. Schenk U, Westendorf AM, Radaelli E, Casati A, Ferro M, Fumagalli M, Verderio C, Buer J, Scanziani E, Grassi F: Purinergic control of $\mathrm{T}$ cell activation by ATP released through pannexin-1 hemichannels. Sci Signal 2008, 1:ra6

37. Vergani A, Fotino C, D’Addio F, Tezza S, Podetta M, Gatti F, Chin M, Bassi R, Molano RD, Corradi D, Gatti R, Ferrero ME, Secchi A, Grassi F, Ricordi C, Sayegh MH, Maffi P, Pileggi A, Fiorina P: Effect of the purinergic inhibitor oxidized ATP in a model of islet allograft rejection. Diabetes 2013, 62:1665-1675

38. Kurashima Y, Amiya T, Nochi T, Fujisawa K, Haraguchi T, Iba H, Tsutsui H, Sato S, Nakajima S, Iijima H, Kubo M, Kunisawa J, Kiyono H: Extracellular ATP mediates mast cell-dependent intestinal inflammation through P2X7 purinoceptors. Nat Commun 2012, 3: 1034

39. Koo TY, Lee JG, Yan JJ, Jang J, Ju KD, Oh KH, Ahn C, Jang J: The P2X7 receptor antagonist, oxidized adenosine triphosphate, ameliorates renal ischemia-reperfusion injury by expansion of regulatory $\mathrm{T}$ cells. Kidney Int 2017, 92:415-431

40. Guile SD, Alcaraz L, Birkinshaw TN, Bowers KC, Ebden MR, Furber M, Stocks MJ: Antagonists of the P2X7 receptor: from lead identification to drug development. J Med Chem 2009, 52: $3123-3141$

41. Subramanyam C, Duplantier AJ, Dombroski MA, Chang S-P, Gabel CA, Whitney-Pickett C, Perregaux DG, Labasi JM, Yoon K, Shepard RM: Discovery, synthesis and SAR of azinyl- and azolylbenzamides antagonists of the P2X 7 receptor. Bioorg Med Chem Lett 2011, 21:5475-5479
42. Lambertucci C, dal Ben D, Buccioni M, Marucci G, Thomas A, Volpini R: Medicinal chemistry of P2X receptors: agonists and orthosteric antagonists. Curr Med Chem 2015, 22:915-928

43. Caseley EA, Muench SP, Fishwick CW, Jiang LH: Structure-based identification and characterization of structurally novel human P2X7 receptor antagonists. Biochem Pharmacol 2016, 15:130-139

44. Keystone EC, Wang MM, Layton M, Hollis S, Mcinnes IB: Clinical evaluation of the efficacy of the $\mathrm{P} 2 \mathrm{X} 7$ purinergic receptor antagonist AZD9056 on the signs and symptoms of rheumatoid arthritis in patients with active disease despite treatment with methotrexate or sulphasalazine. Ann Rheum Dis 2012, 71:1630-1635

45. Stock TC, Bloom BJ, Wei N, Ishaq S, Park W, Wang X, Gupta P, Mebus CA: Efficacy and safety of CE-224,535, an antagonist of P2X7 receptor, in treatment of patients with rheumatoid arthritis inadequately controlled by methotrexate. J Rheumatol 2012, 39: $720-727$

46. Eser A, Colombel J-F, Rutgeerts P, Vermeire S, Vogelsang H, Braddock M, Persson T, Reinisch W: Safety and efficacy of an oral inhibitor of the purinergic receptor $\mathrm{P} 2 \mathrm{X} 7$ in adult patients with moderately to severely active Crohn's disease: a randomized placebocontrolled, double-blind, phase IIa study. Inflamm Bowel Dis 2015, 21:2247-2253

47. Han J, Liu H, Liu C, Jin H, Perlmutter JS, Egan TM, Tu Z: Pharmacologic characterizations of a P2X7 receptor-specific radioligand, [11C]GSK1482160 for neuroinflammatory response. Nucl Med Commun 2017, 38:372-382

48. Fougerousse F, Bartoli M, Poupiot J, Arandel L, Durand M, Guerchet N, Gicquel E, Danos O, Richard I: Phenotypic correction of alpha-sarcoglycan deficiency by intra-arterial injection of a musclespecific serotype $1 \mathrm{rAAV}$ vector. Mol Ther 2007, 15:53-61

49. Pacak CA, Conlon T, Mah CS, Byrne BJ: Relative persistence of AAV serotype 1 vector genomes in dystrophic muscle. Genet Vaccin Ther 2008, 6:14

50. Pacak CA, Walter GA, Gaidosh G, Bryant N, Lewis MA, Germain S, Mah CS, Campbell KP, Byrne BJ: Long-term skeletal muscle protection after gene transfer in a mouse model of LGMD-2D. Mol Ther 2007, 15:1775-1781

51. Rodino-Klapac LR, Lee JS, Mulligan RC, Clark KR, Mendell JR: Lack of toxicity of alpha-sarcoglycan overexpression supports clinical gene transfer trial in LGMD2D. Neurology 2008, 71:240-247

52. Cordier L, Hack AA, Scott MO, Barton-Davis ER, Gao G, Wilson JM, McNally EM, Sweeney HL: Rescue of skeletal muscles of gamma-sarcoglycan-deficient mice with adeno-associated virusmediated gene transfer. Mol Ther 2000, 1:119-129

53. Goehringer C, Rutschow D, Bauer R, Schinkel S, Weichenhan D, Bekeredjian R, Straub V, Kleinschmidt JA, Katus HA, Müller OJ: Prevention of cardiomyopathy in delta-sarcoglycan knockout mice after systemic transfer of targeted adeno-associated viral vectors. Cardiovasc Res 2009, 82:404-410

54. Li J, Dressman D, Tsao YP, Sakamoto A, Hoffman EP, Xiao X: rAAV vector-mediated sarcogylcan gene transfer in a hamster model for limb girdle muscular dystrophy. Gene Ther 1999, 6:74-82

55. Li J, Wang D, Qian S, Chen Z, Zhu T, Xiao X: Efficient and longterm intracardiac gene transfer in $\delta$-sarcoglycan-deficiency hamster by adeno-associated virus-2 vectors. Gene Ther 2003, 10:1807-1813

56. Mendell JR, Rodino-Klapac LR, Rosales XQ, Coley BD, Galloway G, Lewis S, Malik V, Shilling C, Byrne BJ, Conlon T, Campbell KJ, Bremer WG, Taylor LE, Flanigan KM, Gastier-Foster JM, Astbury C, Kota J, Sahenk Z, Walker CM, Clark KR: Sustained alpha-sarcoglycan gene expression after gene transfer in limb-girdle muscular dystrophy, type 2D. Ann. Neurol 2010, 68:629-638 